University of Louisville

ThinkIR: The University of Louisville's Institutional Repository

$5-2018$

\title{
T socio-ecology of managed honeybees (apis mellifera) in the Louisville Metro area.
}

Haileigh M. Arnold

University of Louisville

Follow this and additional works at: https://ir.library.louisville.edu/etd

Part of the Apiculture Commons

\section{Recommended Citation}

Arnold, Haileigh M., "T socio-ecology of managed honeybees (apis mellifera) in the Louisville Metro area." (2018). Electronic Theses and Dissertations. Paper 2915.

https://doi.org/10.18297/etd/2915

This Master's Thesis is brought to you for free and open access by ThinkIR: The University of Louisville's Institutional Repository. It has been accepted for inclusion in Electronic Theses and Dissertations by an authorized administrator of ThinkIR: The University of Louisville's Institutional Repository. This title appears here courtesy of the author, who has retained all other copyrights. For more information, please contact thinkir@louisville.edu. 


\title{
THE SOCIO-ECOLOGY OF MANAGED HONEYBEES (Apis mellifera) IN THE LOUISVILLE METRO AREA
}

\author{
By Haileigh M Arnold
}

B.S, University of Louisville, 2014

\author{
A Thesis Submitted to the Faculty of the \\ In Partial Fulfillment of the Requirements \\ For the Degree of \\ Master of Science \\ In Interdisciplinary Studies: Sustainability \\ Interdisciplinary Studies \\ University of Louisville \\ Louisville, Kentucky
}

School of Interdisciplinary and Graduate Studies of the University of Louisville

May 2018 

THE SOCIO-ECOLOGY OF MANAGED HONEYBEES (Apis mellifera)

IN THE LOUISVILLE METRO AREA

By Haileigh M Arnold

B.S, University of Louisville, 2014

A Thesis Approved on

May 1, 2018

By the following Thesis Committee:

Dr. Margaret Carreiro, Director

Dr. Perri Eason

Dr. Lisa Markowitz 


\section{ACKNOWLEDGEMENTS}

For helping me start and finish my journey into the Interdisciplinary world of Sustainability studies and providing knowledge and guidance regarding Urban Ecology, I thank my advisor Dr. Margaret Carreiro. Thank you, as well, to Dr. Lisa Markowitz for her valuable anthropological point of view and to Dr. Perri Eason for her knowledge of insect biodiversity and encouragement while serving on my committee. I also need to thank my professors Lauren Heberle and Angela Storey, whose classes informed and inspired the Political Ecology chapter in this thesis. My thesis would also not exist without the cooperation of the beekeepers included in my study in the Kentuckiana Beekeepers Association and Kentucky State Apiarist Tammy Horn. Software and Data used for GIS analysis was provided by the LOJIC database through the University of Louisville. Thank you to the School of Interdisciplinary and Graduate Studies at the University of Louisville by supporting me with a fellowship position during my studies. Finally, thank you to my mom for encouraging me to keep learning, my husband for encouraging to keep working, and the rest of my friends and family for their support. 


\title{
ABSTRACT \\ THE SOCIO-ECOLOGY OF MANAGED HONEYBEES (Apis mellifera) IN THE LOUISVILLE METRO AREA
}

\author{
Haileigh $\mathrm{M} \square$ Arnold
}

May 1, 2018

Humans have a long history of the practice of beekeeping to harness the power of pollination while gaining honey and other products as well. This managed pollinator system consists of beekeepers, honeybees, and their environment. However, recent disease, pesticide use, and land use factors honeybee threaten this relationship. In the face of such concerns it is important to examine the factors that impact and can help sustain our managed pollinator systems. In this thesis, the national and Kentucky state-level policies that affect managed pollinator systems were examined and socio-ecological factors that may contribute to honeybee hive growth and losses were assessed along an urban development gradient in Louisville, KY metropolitan area. Chapter 1 provides a brief review of the honeybee managed pollinator system in relation to sustainability and describes the conceptual framework used in this study. In Chapter 2, national and state policies and plans are described, trends and gaps within them analyzed for their impact on beekeepers, and possible improvements discussed. This policy analysis revealed that policy is shifting from prioritizing commercial beekeeping and economic solutions to more public engagement and research-based solutions through the implementation of pollinator protection plans and public-private partnerships. In Chapter 3, potential socioecological determinants of honeybee hive growth were explored using a survey of Louisville area beekeepers and classification of hive sites along an urban-rural gradient based on percent impervious area. Land use did not significantly explain any variation while beekeeper experience were trends and motivation was significant for hive gain. These results suggest that the success of this managed pollinator system in the Louisville area depend on policies and well informed decision-making by beekeepers. 


\section{TABLE OF CONTENTS}

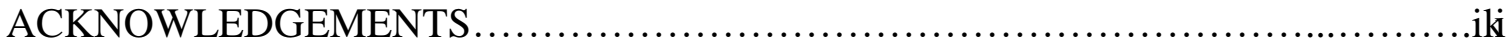

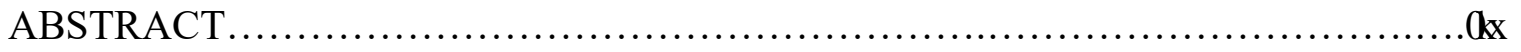

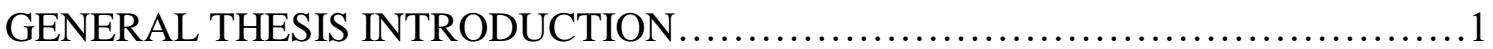

THE INFLUENCE OF NATIONAL AND STATE POLICY

ON BEEKEEPERS IN KENTUCKY ........................................ 14

EXPLORING THE SOCIO-ECOLOGICAL DETERMINANTS OF

HONEYBEE (Apis mellifera) HIVE CONDITION AND COLONY GROWTH

IN THE LOUISVILLE METRO AREA...................................45

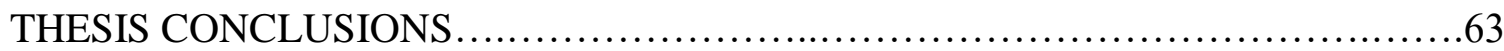

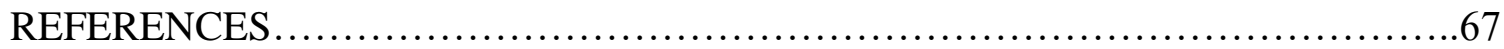

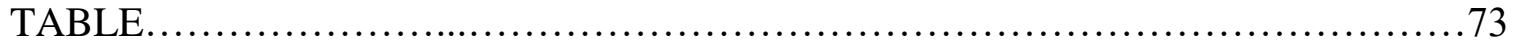

FIGURES............................................................. 74

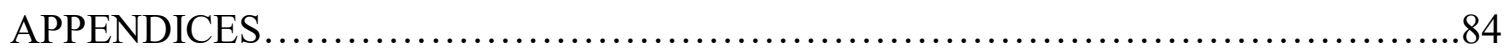

CURRICULUM VITAE .................................................... 100 


\section{CHAPTER 1}

\section{INTRODUCTION}

\section{$\underline{\text { Introduction }}$}

The academic study of sustainability is diverse in definitions, applications, topics, and methods (IUCN, 1980; U.N, 1987; Kates, Parris, T. M., \& Leiserowitz, 2005; Hassan, Scholes, \& Ash, 2005; Lemonick, 2009). However, a typical attribute of any study of a sustainability related issue is complexity. Sustainability issues take into account multiple environments, scales, and subjects in order to have as holistic a view of systems as possible in order to better understand these systems and how to sustain them over time. This study of beekeepers and the honeybee populations they manage in the cities and suburbs in and around Louisville, Kentucky takes this sustainability approach by examining the potential effects on this mutualistic relationship of natural, built, and social environments at individual, state and national scales. This study attempts to analyze parts of a complex web of interactions among beekeepers, honeybees, the biophysical environment, beekeeper associations, government employees, and policy. The content of this thesis stands as a representation of some of the information I have gathered. This information is intended to support ongoing research efforts on the sustainability of beekeeping. Therefore, this chapter explains what sustainability is, how it relates to the research for this thesis. This chapter also describes the conceptual framework used for this thesis, and the content of each chapter. 


\section{Sustainability}

The overarching theme that connects the chapters of this thesis is sustainability. There are different definitions and frameworks for this concept that incorporate its inherent interdisciplinary nature and result in its conceptual flexibility. For this section I explain some definitions of sustainability, apply a sustainability framework to my study system, and highlight some current issues that threaten the sustainability of our mutualism with honeybees.

Sustainability as a concept began by focusing on the tensions created by the growing need to conserve of nature and the need for societal development. (International Union for the Conservation of Nature (IUCN), 1980). The IUCN focused on the tension between conservation and societal development trying to meet the needs of people in the present and the future. They concluded that these two opposing processes could work together in the form of sustainable development and theorized that sustainable development should result in more stable and longer-lasting socio-ecological systems. This concept was later defined by the United Nations World Commission on Environment and Development as "development that meets the needs of the present without compromising the ability of future generations to meet their own needs" (U.N, 1987; Lemonick, 2009). In other words, sustainable development is development that focuses on intergenerational equity by carefully developing with nature in mind in order to maintain ecosystem functions and resources for future use.

These definitions focused on the natural and built environments, but grew to incorporate more systems to be sustained and developed. Sustainable development now 
includes a goal of achieving equity between different communities of people in society (Wheeler, 2000; Kates, 2005). Though these definitions are framed with development in mind, there are some key concepts within them that apply to sustainability as a whole, including intergenerational equity, socio-economic equity, complexity, multi-scaling, and longevity.

For this thesis I will use the following definition of sustainability based on these sources (IUCN, 1980; U.N, 1987; Wheeler, 2000; Kates, 2005; Lemonick, 2009) and key concepts. Sustainability in academia is the study of complex webs of interactions among different socio-ecological systems so that informed action can be undertaken to keep those systems functioning and equitable over an extensive period of time for the benefit of current and future generations. A systems approach and framework can be useful for such analyses of complex interactions since it identifies main components and the types of relationships between them. In this study of the beekeepers, honeybees, and society in cities and suburbs, the main interacting components that affect the focal subsystem (the managed honeybee system) are the natural, social, and built environments.

\section{Natural Component- The Honeybees}

The natural component of the managed pollinator system are the domesticated honeybees in the genus Apis $(L)$. To appreciate and understand their function in the natural environment, it is necessary to discuss their ecological value and economic value to society, which includes their ecosystem service of pollination.

Pollination is vital to food production because it starts the process of sexual reproduction in angiosperms, or flowering plants that creates fruits that other living 
things consume. Various birds, insects, and mammals co-evolved with many plants to help with this process (Martin et al., 1980, p.107-113; Jones \& Sweeney-Lynch, 1958/2011, p.119). One pollinator group in particular has a monopoly on pollinator domestication, the honeybees. These pollinators, taxonomically placed the genus Apis, consist of seven species that diverged into 44 subspecies around the world (Engel, 1999; ITIS 2008; Engel, Hinojosa-Diaz, \& Rasnitsyn, 2009). Of these species two are considered domesticated, Apis cerena indica (a subspecies of Asiatic honeybees, the Indian honeybee) and Apis mellifera (the Western or European honeybee) (Jones, 1958/2011; Webster, 1977/2013; Putra, Agus, \& Syayidah, 2014; Beaurepaire et al., 2015; Matias, Borgemeister,\& Wehrden, 2017). All bees gather nectar and pollen to eat, but honeybees create permanent hives for this purpose that last throughout the year and establish populations that contain tens of thousands per hive (Jones, 1958/2011; Martin et al., 1980; Webster, 1977/2013).

As explained in the Millennium Ecosystem Assessment (Hassan et al., 2005), pollination is an ecological service with economic value to society because it is vital to the continued existence of both natural ecosystems as well as human-dominated agroecosystems. Its role in plant life cycles directly affects the continuation of natural systems such as forests and meadows, which themselves provide services to society, such as flood control, maintenance of water and air quality, and biodiversity preservation (Hassan et al. 2005). However, pollination's most financially assessable contribution is to the maintenance of agroecosystems that require insect-vectored pollination. One study found that $70 \%$ of the main crop species grown for human consumption are dependent on honeybees and native pollinators, which provided an estimated global value of over 153 
billion Euros in 2005 (Gallai, Salles, Settele, \& Vaissière., 2009). A recent meta-study found that honeybees accounted for $>25 \%$ of crop visits by pollinators in 21 different studies from around the world (Garibaldi et al., 2011). Other studies have found that in areas of Europe honeybee contributions can be over 80\% (Gallai et al., 2009; Lecocq, Kryger, Vejsnæs, \& Jensen, 2015).

Beekeepers also charge for this pollination service, usually $50-150 \$$ per hive (Webster, 1977/2013, p. 79; Bush, 2004, p. 27). For commercial beekeepers, this service can result in substantial profit. For example, the value of pollinator services on blueberry farms in Michigan, U.S.A has been estimated to be $\$ 124$ million a year (Juniper, 2013, p. 116). Human-assisted migration of hives is a critical contributor to production in the U.S.A, with up to 40 billion bees being moved to the almond orchards of California, then trucked to Florida for citrus, Northern states for apples and cherries, and Maine for blueberries (Jones, 1958/2011). Overall, honeybees' ecosystem service of pollination is of great value to the natural environment and to human society as well.

\section{$\underline{\text { Social- The Beekeepers }}$}

Given that pollination is vital to food production, it is no surprise that humans have had a long history of managing pollinators, specifically different species of honeybees. According to accounts of beekeeping history in The Beekeeper's Bible (Jones, 1958/2011), the domestication of honeybees began as early as 2400 B.C in ancient Egypt, where preserved hives can still be found today. Evidence of early beekeeping also exists in the form of ancient glyphs, codices and writing has been found all over the world in Sub-Saharan Africa, Mesoamerica, India, China, and Rome, 
reflecting the worldwide distribution of different species of Apis. In the Middle Ages beekeeping with Apis mellifera established a hold across Europe with development of hives that were grass-weaved baskets called skeps. Eventually the practice was taken to the New World with European settlers (Jones, 1958/2011; Horn, 2006, p. 19-26). Shipping information indicates that European honeybees were transported from England to the Colony of Virginia in 1622 (Martin et al., 1980, p. 2; Horn, 2006, p. 20). Honeybees and beekeepers spread across the United States of America (U.S.A) as immigration expanded westward and increasingly became a part of American culture (Horn, 2006, p. 30-84). The invention of a new kind of hive by Langstroth in 1852 allowed beekeepers to manage hives more conveniently since the frames were easier to inspect and extract honey from. This paved the way for even larger scale beekeeping. (Martin et al., 1980, p. 3; Horn, 2006, p. 68).

Commercial beekeeping started in multiple locations across the U.S.A in the $19^{\text {th }}$ century. In the 1860 's, beekeeping companies were established that still exist to this day (Martin et al., 1980, p. 5; Horn 2006, p. 112-114). With the development of the transportation industry came the development of the pollination industry. This included the establishment of migratory pollination services on the West Coast once the Union Pacific Railroad started transporting hives from Utah to California for pollination in the winter months (Martin et al., 1980, p. 5-6; Horn, 2006, p. 148-149).

Commercial beekeeping has since grown as greater knowledge and innovations in beehive design increased bee survival and honey productivity. For example, the Langstroth is still considered the "standard" hive type in the U.S.A, especially for commercial beekeeping (Horn, 2006; Horn, personal interview, Febuary $23^{\text {rd }}, 2018$; 
Martin et al., 1980:46-47; Fig. 1). Other innovations like pre-patterned hive frame foundations, honey extractors, bee smokers, and protective gear made beekeeping easier and safer. The demand for honey grew with new marketing, partnerships with the agricultural sector, support from national policy, and the creation of new products (Jones, 1958/2011; Martin et al., 1980, p.4-7\&182-185; Horn, 2006, p. 160-168). Highway construction after WWI provided efficient transportation connectivity, which also encouraged growth, and by 1957 there was an estimated 1,200 professional beekeepers operated 1.44 million colonies in the U.S.A (Martin et al., 1980, p. 5).

With the expansion and growth of beekeeping, came widespread manageable pollination services and products. However, the beekeepers as actors in their social environment permanently altered the natural environment by introducing honeybees where they previously had not existed. These honeybee introductions have increased competition between the non-native honeybees and other native pollinators, which is a conservation concern today (Thomson, 2004). In addition, the establishment and growth of commercialized and migratory beekeeping brought threats of spreading disease, parasites, and fungi across the country and the globe to both honeybee and native pollinator populations (Martin et al., 1980, p. 118-127; Kristine, et al., 2013; Putra et al., 2014).

\section{Built- Their Environment}

The built environment is often seen at the counterpart to the natural environment, both taking up physical space. The natural environment can be described as areas established and maintained by natural processes, and the built environment as areas 
established and maintained by human activity. However, manmade "built" areas are still affected by the natural environment, and vice versa.

As more people have shifted to living in cities and suburbs in the U.S.A, beekeeping across an urban to rural gradient has become more prevalent and growing in popularity (Williams, Corbet, \& Osborne, 1991; Clermont, 2015; Lecocq et al., 2015; Lorenz \& Stark, 2015; Lowenstein, Matteson, \& Minor, 2015; Sponsler \& Johnson, 2015). This results in a different environmental context for honeybees and their hives, with hobbyist beekeepers possibly providing local natural areas and residential gardens with pollination services. Lecocq et al. 2015) found that when analyzing the impacts of surrounding landscapes, urban hives were more productive than hives in agricultural or mixed landuse areas. Studies have suggested that this may be due to the variety of plants grown in cities and suburbs and to urban planning that includes parks, gardens, and natural areas (Lecocq, et al., 2015; Lowenstein, 2015). However, it has also been shown that urban hives have a higher risk of sudden colony die-off (Clermont, Eickermann, Kraus, Hoffmann, \& Beyer, 2015). This does demonstrate that beekeeping can be successful in built areas, but not without some potential negative impacts from the built environment and its management.

Debates continue about the exact cause of the decline in bee populations worldwide. However, some reasons stem from human management and alterations of the environment. Current hypotheses include pests, insecticides, monoculture crops, and land use change (Webster, 1977/2013, p. 41; Bush, 2004, p. 107; Dave, 2013; Putra, 2014). Some of these factors cause direct mortality but others such as neonicotinoids (a common pesticide) do not. In the case of neonicotinoids, the effects are sub-lethal but contribute to 
subsequent death by diminishing learning, foraging, and homing abilities in honeybees (Henry et al., 2012; Dave, 2013; Juniper, 2013). These factors could also make honeybees more susceptible to other more well-known hive infestations, such as Varroa mites, beetles, moths, and microbes that can invade hives (Bush, 2004, p. 36).

\section{Sustaining Managed Pollinators}

As pollination services become more threatened by global change factors like land-use change and climate disruption, beekeeping becomes an increasingly important contributor to human sustainability. The consequences of pollinator loss have already affected areas of the world and currently there are two solutions: pay for, borrow, and transfer hives to where pollination is needed, or pollinate by hand. Both of these methods are very costly due to having to pay other humans for the service that the wild pollinators were providing for free (Juniper, 2013, p. 112). Therefore, supporting pollinators before they are lost is very important for our natural, social, and built systems.

One way to support honeybees is by managing them with the practice of beekeeping. Because beekeeping is affected by the built, natural, and social environment, it therefore qualifies as a socio-ecological system that is important to understand and maintain. The built components exist at various scales and include the hive itself and physical features of the surrounding land cover and use, such as pavement, buildings, and roads that alter air quality levels and surrounding heat. Natural components consist of the honeybees themselves, other organisms that can coexist in the hive as pests and diseases, the types of natural and semi-natural spaces with natural or human-selected floral resources, and other biota, such as predators or competitors, that honeybees may interact 
with outside the hive. The beekeepers themselves, their abilities, management styles and their degree of interaction with higher level social, political and economic structures comprise the social environment affecting the honeybees. All of these factors come together and affect the success of managing honeybees. It is, therefore, important to determine what factors are the most impactful so that positive variables and activities can be supported and negative ones reduced. That is the intent of this thesis, achieved by investigating the social, natural, and built pressures in this managed honeybee study system. For the remainder of this chapter I will explain the study system I worked with, the framework used to analyze it, and the content of Chapters 2 and 3.

\section{Study System}

As explained above beekeepers, honeybees, and their distribution are all components of the social, natural, and built environments. The challenge to maintain this web of interaction in the face of widespread pollinator decline is a sustainability issue. This study focuses on beekeeping and seeks to investigate the influence of the natural, social, and built environment on colonies of the European honeybee (Apis mellifera), hive condition, honeybee population growth, and honey production. The conceptual framework (Fig. 2) identifies factors that are likely to contribute to the distribution, survival, growth, and productivity of honeybee populations in an urban, suburban, and rural contexts. 


\section{Framework Explanation}

In this thesis framework (Fig. 2) the socio-political context (Box 1) influences beekeepers (Box 2) and their surrounding land use (Box 3) by affecting the social support, provision of resources, policies regarding beekeeping, and land-use decisions. These in turn affect honeybee hive distribution and condition (Box 4), resulting in varying levels of bee population growth and loss (Box 5) and surplus honey production (Box 6).

The Socio-Political Context (Box 1) for the purpose of this study is viewed as an aggregate of the knowledge of individuals shared by a community or social group, the social systems they reside in, and the policies under which they operate. The SocioPolitical Context directly affects Beekeepers (Box 2) and the hive management decisions they make. In this study, social systems include beekeeper associations and the federal and state government. Both of these are important systems for connecting beekeepers to others, sharing knowledge, providing financial support, and creating policies that influences the beekeepers and their decision-making processes. The beekeepers make decisions about where to establish their hives and how to manage them. Their decisions directly affect the hive distribution and condition (Box 4), which in turn influence honeybee population growth and loss (Box 5), and the amount of honey made by the colony (Box 6).

The Socio-Political Context (Box 1) also shapes the physical landscape and available resources through land-use decisions. These collective decisions are made from social knowledge and governance systems. Land Use and Land Cover (LULC) (Box 3) is 
the result of these decisions and can affect honeybee survival. These varying factors include impervious surface cover, types of land use such as residential, agricultural, commercial and industrial, all of which can influence water availability, the amount and types of vegetation, and hence nectar and pollen resources, close to hives. These LULC factors are also determinants of the degree of heat, pollution, and pesticides in the environment surrounding the hives and their flowering plant resources. Therefore, these LULC factors along with the beekeepers and their decisions are expected to affect where beekeepers can establish hives and their condition (Box 4), the productivity and survivability of honeybees (Box 5), and their honey production (Box 6).

\section{$\underline{\text { Content of Succeeding Chapters }}$}

After conducting research to answer these questions, my findings are compiled in the next two chapters. Each chapter follows the general outline of introduction, theory, methods, findings, analysis and discussion. Chapter two focuses on the Political Ecology of beekeeping for the Louisville Metro area of Kentucky. The findings come from analyzing Federal and State laws and publications. The analysis of these policies is expanded and supplemented by interviews with Tammy Horn. Tammy is the State Apiarist for the Kentucky Department of Agriculture and in charge of identifying and eradicating infectious diseases in honeybee colonies, helping educate the general public about honeybees and their services, and offering best practice advice to beekeepers. Chapter three focuses on the potential effects of urban, suburban and rural LULC on the growth dynamics of honeybee colonies in the Louisville Metro Area. Information for this 
chapter comes from the surveying of beekeepers in Jefferson, Spencer, Shelby, Bullitt, and Oldham Counties primarily through the Kentuckiana Beekeepers Association. I began to attend association meetings at the beginning of my research to recruit people for my surveys and eventually became a member myself. 


\section{CHAPTER 2}

\section{THE INFLUENCE OF NATIONAL AND STATE POLICY ON BEEKEEPERS IN KENTUCKY}

\section{$\underline{\text { Introduction }}$}

The three core components of sustainability, the natural, social, and built environments, often overlap to create complicated webs of interaction. In this chapter I focus on relationships between managed honeybee populations and the governmental policies that affect beekeepers as an example of how natural and social components of our environment interact. Socio-Political regulations, support, and incentives affect beekeepers as a group and as individuals through policies at multiple levels. Before focusing on local scale determinants of hive success in the Louisville area (Chapter 3), it is important to understand that the socio-political norms beekeepers operate under affect beekeeper decision making. These decisions in turn affect the placement and wellbeing of their honeybee hives.

Therefore the primary questions addressed in this chapter are:

1) What national and state policies have been established and why?

2) How might those policies affect beekeepers and their practices? 
3) How might policies directly and indirectly affect the sustainability of managed pollinators?

To provide context, I will first explore how these questions fit into a broader Political Ecology framework. Then I will explain my approach and methods to answering these questions. My policy analysis has two major sections for the different scales of policy. The first section contains current national policies in the U. S. A. and the second section contains current Kentucky state policy. Each section consists of summarizing past and current policies that pertain to beekeepers, followed by analyzing the trends, issues, and impacts, and ending with a discussion on how these issues could be addressed. I then conclude with a discussion of how policies at national and Kentucky state scales are similar and their impacts on the sustainability of beekeeping.

\section{Theory}

For this chapter I examine policy because it is socially constructed, and affects the physical environment directly and indirectly. This idea is the foundation of the discipline of Political Ecology, which aims to address questions regarding this relationship between policy and its environmental and socioeconomic impacts (Greenburg \& Parks, 1994;

Keil, 2003; Robbins, 2012). Like sustainability, Political Ecology lies at a crossroads that invites multiple disciplines, methods, and points of view. In the establishment of the Journal of Political Ecology, James Greenberg and Thomas Park (1994) emphasize the interdisciplinary nature of the field by welcoming case studies from a variety of specialists. With a field of study so diverse, pulling from anthropology, sociology, 
ecology, economics, law, history, and more, it is to be expected that there is significant variation in methods, vocabulary, and theory. However, they explain that there are two "theoretical thrusts" that shaped the formation of Political Ecology. They explain the formation of Political Ecology as an extension of Political Economy and Ecology, each bringing its own theories and methods to this newer discipline.

Political Economy examines power and the policies that come from those in power and how they affect others in society through economic means. One key aspect from Political Economy is the insistence that the formation of policy and its effects are intentional, not coincidental. Ecology on the other hand provides models that conceptualize structures and processes in the biological and physical environment that may affect social processes and vice versa (Greenberg \& Parks, 1994). Political Ecology was built on the intersection of the two disciplines, resulting in studies on relationships between policy and its socio-ecological impacts, often discussing how power dynamics between government, non-governmental entities, and citizens impact their environment (Greenberg \& Parks, 1994; Keil, 2003; Robbins, 2012, p. 16,22-24). Although, Greenberg and Parks conclude, Political Ecology studies “....need not to share a common core" and its studies need only contribute to "... an increased understanding of the interactions between political and environmental variables broadly conceived".

In the remainder of this chapter I investigate the political ecology of beekeeping in Kentucky, U.S.A on the national and Kentucky state levels. These policies have the power to impact local beekeepers and their hives through the framing of honeybees, financial assistance, valuation of honeybees, and promoting research. Therefore, the broad question I address is: How does the socio-political context under which beekeepers 
operate affect them and their hives? To do this I first describe the content and reoccurring trends within national and state level policies. I then analyze the benefits and detriments of these policies and discuss how these policies could be changed to better serve beekeepers.

\section{$\underline{\text { Methods }}$}

My sources for the policies and their subsequent analysis are the United States Federal Government and Kentucky State Government legislature with supporting documents from United States Department of Agriculture (USDA) and the Kentucky Department of Agriculture (KDA). Federal Laws were found by using the online database of the United States Code which is "a consolidation and codification by subject matter of the general and permanent laws of the United States (URL in References). It is prepared by the Office of the Law Revision Counsel of the United States House of Representatives". The laws themselves were found in this database beginning with the search terms "honey", "beekeeping", "honeybee", "bee”, and "honey research". The resulting Laws are coded by: Title, Chapter-Section (Year Enacted). The search results were found within Title 7 in Chapters 11,35A, 36, 77, 88, and 115, and these chapters were browsed in their entirety. The State law and Kentucky Pollinator Protection Plan were found by contacting the Kentucky State Apiarist, Tammy Horn, who informed me of where to find both on the Kentucky Department of Agriculture website and the Kentucky Revised Statutes Database (URL in References). Tammy Horn was also interviewed on February $23^{\text {rd }}$, 2018 with questions regarding national and state policies 
and the Kentucky Pollinator Protection Plan. I became a member of the Kentuckiana Beekeepers Association and attended their monthly meetings from the summer of 2016 to the present in order to learn about the potential impact of policy on local beekeepers.

\section{$\underline{\text { Policy Analysis }}$}

For the policy analysis I first focus on the United States national policy and then Kentucky state policy, explaining their contents, describing trends, analyzing its impact on beekeepers, and discussing potential improvements for each level.

\section{$\underline{\text { National Policy }}$}

The spread of honeybee diseases has been a primary reason for drafting national scale policies concerning beekeeping in the United State. The spread of American foulbrood caused by the bacterium Paenibacillus larvae, various viruses carried by Varroa destructor or "Varroa mite", and more recently Colony Collapse Disorder are some of the threats to honeybees due primarily to migratory beekeeping practices, where commercial beekeepers move hundreds of hives to different agricultural locations to provide pollination services (Jones, 1958/2011; Martin et al., 1980:4). The spread of these pests and diseases have increased hive losses and negatively affected both honey production and the pollination service industry in the U.S.A. Therefore, many federal level regulations have been passed to deal with these issues by limiting hive movement, financially supporting the honey industry, and funding research. However, a broader, more holistic framework of support has been developed in recent years by the Pollinator Protection Plans. 


\section{Movement Limitations}

The growth of beekeeping into an industry in the U.S.A was built upon the importation of bees from Europe. Therefore, the first federal legislation to be enacted concerning honeybees addressed importation. The "Honeybee Act" (7, § 11-281 (1922)) restricted the importation of living adult honeybees from anywhere outside of the U.S.A. This act has been amended throughout the years to include all species of honeybee (Apis), not just the European honeybee (Apis mellifera) in 1962. In 1976, the act also included all life stages and germ plasm, and in 1994 the ability to destroy or export hives that have been offered for import or intercepted. Section 282 created in 1922 and amended in 1976 states that any person who violates the Honeybee Act is guilty of an offense against the United States and will be fined up to $\$ 1,000$ and/or imprisoned up to a year $(7, \S 11-282$ (1922)).

\section{Honey Price Support}

As with other agricultural products, honey is a commodity that is supported financially by the federal government, legislated primarily by the Agricultural Act of 1949 (also known as the Farm Bill) in the form of "loans, purchases, or other operations" as deemed necessary by the Secretary of Agriculture (7, § 35A- 1446 (1949); Martin et al., 1980, p. 182). The Commodity Credit Corporation (CCC) is an agency within the United States Department of Agriculture that offers marketing assistance loans during harvest time, when honey prices would be the lowest. These loans pay beekeepers for their honey, but if market prices rise within 9 months of the loan, beekeepers can pay back the loan and sell their honey instead (Thompson, 1993; USDA, 2014; USDA, 2018). 
However, as with other price support legislation for agriculture, it has been revisited and can be deemed "inapplicable" during the budget process. From 1954 to 1990, a series of modified amendments changed which industries received price support by creating new amendments and terminating the previous amendment. Subsequently, new sections of The Agricultural Act have been added that specify a specific time period of 4 years before the act is revisited.

\section{Emergency Assistance}

In addition to providing price support for the honey market, there is legislation for establishing and maintaining an Emergency Relief Fund for farmers and beekeepers. According to Tammy Horn (Kentucky State Apiarist), an early form of this concept was the USDA Hive Indemnity Program, which was initiated in the 1980s when Varroa mite infestations became widespread and hive losses were as high as $80 \%$. However, this program was abused by people who did not own hives and were claiming losses. Tammy concluded that the skyrocketing number of self-reported "beekeepers" was evidence of people taking advantage of the program. In 2008, the Supplemental Agricultural Disaster Assistance Act (subsection e) was passed to help farmers in times of emergency and is currently funded by the Agricultural Act. This act states that emergency relief will be provided to producers of honeybees to help with losses resulting from disease, adverse weather, and other conditions (7, $\S 36-\mathrm{II}-1531)$. Relief is handled by the Emergency Assistance for Livestock, Honeybees, and Farm-Raised Fish Program administered by USDA. This program supports beekeepers financially by compensating for hive, colony, or feed loss. However, to qualify the beekeeper's colony must be “producing honey, pollinating or breeding operation for commercial use as part of a farming operation" 
(USDA, 2017). New sections were subsequently added to limit the total amount for the programs and to limit the amount an individual can receive $(7, \S 115-9081$ (2012).

Research

Support for research related to honeybees, the honey industry, and beekeeping is included in several different chapters under Title 7 and varies with context and focus. Chapters that include beekeeping research are 11-Honeybees, 35A- Price Support of Agricultural Commodities, 36- Crop Insurance, 77-Honey Research, Promotion, and Consumer Information, 88-Research, and Chapter 115-Agricultural Commodity Policy and Programs.

Chapters 11 and 36 support research agendas intent on limiting hive movement and evaluating the ability of programs to protect the commercial honey trade. Chapter 11 (the Honeybee Act) contains sections aimed at limiting honeybee movement to lessen the spread of diseases. In section 284 , this is broadened to include "undesirable species and subspecies" (not defined) and research regarding their movement. This section authorizes the Secretary of Agriculture to cooperate with governments from particular countries to carry out research involving the "spread of undesirable species and subspecies of honeybees" (7, § 11-284). Chapter 36 contains the regulations regarding the Federal Crop Insurance and Supplemental Agricultural Disaster Assistance aimed at supporting honey and beekeepers financially. Section 1522 of this chapter focused on funding research and development to determine the effectiveness of insurance policies in covering honeybee losses. (7, § 36-I-1522). 
Unlike the other chapters, chapter 77 (the Honey Research, Promotion, and Consumer Information Act) focuses solely on the honeybee industry by establishing the process for honey research, promotion, and consumer information. One specific purpose of this chapter is to "sponsor research to develop means of dealing with pest and disease problems". However, research objectives are not clearly stated in this chapter. Instead it focuses on the process of management by the Secretary of Agriculture $(7, \S 77-4601$ 4613)

Chapter 88 explicitly establishes specific research objectives across the agricultural sector, including broader pollinator protection. The policy for this research states that research and extension grants may be made to support research on pollinators in general, not just the honeybee. Some objectives reflect the current concerns regarding honeybee production, health, colony collapse disorder, parasites, pathogens, sub-lethal insecticide, herbicide, and fungicide effects, and best management practices. Colony collapse disorder is prioritized and the Secretary of Agriculture is given the responsibility of expanding the Department of Agriculture to address and research colony collapse disorder and other long-term threats. This act requires that the Secretary of Agriculture submit an annual report including research findings, management practices, and recommendations for policy. From 2008 to 2018, \$10,000,000 in grants were given annually for this research. This section also authorized the use of $\$ 2,750,000$ each year from 2008-2018 to conduct a "nationwide honeybee pest, pathogen, health and population status surveillance program". One result of these authorizations and budgets have been the Bee Informed Partnership, which was initially supported by USDA and National Institute of Food and Agriculture grants to gather larger amounts of data by 
surveying beekeepers across the nation online, and sampling and monitoring the health of registered sentinel hives (Bee Informed Partnership, 2018). This partnership provides open data, interactive tools, and results about a variety of hive health topics, some of which will be used and discussed in chapter 3 of this thesis.

\section{Pollinator Protection Plan}

After years of focusing on movement limitations, honey price support, emergency assistance, and haphazard research, the Obama Administration released the "Creating a Federal Strategy to Promote the Health of Honeybees and Other Pollinators" on June 20, 2014. This program was created as a response to growing concerns over pollinator losses (Obama, 2014). It begins with recognizing the importance of not only honeybees but also other pollinators to the sustainability of our agroecosystems, including the threat of native pollinator losses, specifically Monarch butterflies and native bees.

"The problem is serious and requires immediate attention to ensure the sustainability of our food production systems, avoid additional economic impact on the agricultural sector, and protect the health of the environment... it is critical to expand Federal efforts and take new steps to reverse pollinator losses and help restore populations to healthy levels." (Obama, 2014)

President Obama officially recognized the threats that many, including Tammy Horn, believe are leading to "the greatest agricultural crisis since the Great Depression" (Horn, personal interview, February 23, 2018) and then took action to address these threats. 
In the next part of this memorandum, President Obama established the Pollinator Health Task Force, which includes the Secretary of Agriculture and the Administrator of the Environmental Protection Agency as co-chairs and additional representation from 14 other stakeholder groups. This task force was entrusted with establishing a pollinator research action plan, public education plan, and engaging with various stakeholders to form recommendations regarding Public-Private partnerships within 180 days of the declaration. To accomplish this requires "studies", "plans", "assessments", "strategies", all of which require research. The memorandum was codified under "High-priority research and extension initiatives" (7, § 88-VII-5925). More specific orders to different departments were given to increase and improve pollinator habitat as well, including using government land for pollinator habitat, establishing a native plant seed bank, minimizing pesticide use, and assisting in the creation of state plans.

After the task force was formed, the members carried out the duties directed by the Obama Memorandum and released the National Strategy to Promote Pollinator Health, Pollinator Research Action Plan, Pollinator-Friendly Best Management Practices for Federal Lands documents in May, 2015. The strategy contains goals, research, budget requests, public outreach plans, and current and planned actions to sustain honeybees, monarch butterflies, and create and maintain more pollinator habitat (Pollinator Health Task Force, 2015 a). For honeybees specifically the plan sets the goal to reduce overwinter colony losses to $15 \%$ by 2025 , to continue and fund research outlined in the Pollinator Research Action Plan (Pollinator Health Task Force, 2015 b), to practice and encourage best management practices outlined in the Pollinator-Friendly Best Management Practices for Federal Lands document, to engage and educate the public in 
supporting pollinators and those working on behalf of them, and to continue to connect with private organizations with a Partnership Action Plan (Pollinator Health Task Force, 2016 ). The Pollinator Research Action plan is also extensive, with ten specific subjects of research to achieve setting a baseline population data for honeybees and native pollinators, assessing environmental stressors, studying how best to restore pollinator habitat, understanding and supporting land managers and beekeepers, and curating and sharing the knowledge from pollinator and plant data (Pollinator Health Task Force, 2015 b). The Pollinator Task Force released the Pollinator Partnership Action Plan in June, 2016. This plan includes examples of successful PPPs and suggests potential opportunities for future PPPs, in order to encourage the establishment of more PPPs between Federal agencies, State/Local governments, private companies, universities, community organizations and other entities. For honeybees specifically, the plan highlights PPPs that are addressing research (miticides, biodiversity, citizen-science, and new technologies), monitoring and extension (Bee Informed Partnership, Cost Of Pollination surveying), risk assessment and pesticide management (gathering data for pesticide research, regulations, and management), and using and managing floral resources, which includes allowing beekeepers to utilize public land and conservation incentive programs (Pollinator Task Force, 2016).

Overall, the Obama Memorandum, its codification into law, and the plans created by the task force reflect the growing concern and need for a response to colony collapse disorder with research being a key component. This research primarily focuses on honeybees, but there are efforts on behalf of Monarch butterflies and other native 
pollinators. Though funding is budgeted for these efforts, the memorandum shifts to an emphasis on using Public-Private Partnerships (PPPs) to achieve these goals.

\section{$\underline{\text { National Analysis }}$}

The rapid decline of pollinators, both native and honeybees, threatens the sustainability of our agroecosystems. What are some of the policies that affect might affect the efficacy of governmental and non-governmental responses to this large-scale sustainability problem? These problematic issues include 1) the classification of honeybees as only agricultural, 2) the FDA's classification of honeybees as a species of minor agricultural importance, 3) the focus on commercial beekeepers, 4) market competition from honey importation, and 5) lack of inclusion of other pollinators and land-use effects in policy research agendas. However, the recent efforts by the Pollinator Task Force address some of these policy insufficiencies.

As seen above, national policy has the power to frame and re-frame how honeybees are viewed in the legislature which in turn affects how they are valued and marketed. Until the Obama Memorandum any consideration of honeybees in policy was restricted to agriculture. The older acts, including the Honeybee Act, Agricultural Act, and Supplemental Agricultural Disaster Assistance Act, all reflect a focus on honeybees as an agricultural species. Therefore, this framing of honeybees as producers of an agricultural commodity also shapes the lens through which honeybees are viewed in policy. Since honeybees are classified as an agricultural species, their societal value is restricted to the economic gain that commercial beekeepers may accrue from charging farmers for pollination services or by selling honeybee products. This ignores the 
valuation and monetization of the important ecological role that honeybees play in their ecosystems. It also means that like other agricultural industries, the primary solution to problems becomes financial support, as seen with the honey price support and emergency fund. Instead of addressing the issue of colony loss by supporting efforts to combat it, the reflexive government default has been to compensate losses.

While the ecological value of honeybees has been unrecognized under law prior to 2014, surprisingly, the more tangible economic contributions of honeybees have also been undervalued. As Tammy Horn pointed out, this is due largely to the FDA classifying honeybees as a minor agricultural species. In her opinion, this policy classification needs to be changed:

"The FDA divides animals into different classes and honeybees are in the...minor species section, we're in the same category as bison, as pheasants, as all of these other species...but honeybees contribute at least 20 billion...to the agricultural economy... that's a reason why we don't have policies" (Horn, personal interview, February, 23 2018)

Her point is that although honeybees and beekeepers generate a lot of economic revenue and are vital to agriculture, they are not getting the attention and protection they deserve from agricultural policy. Though the classification of honeybees as a minor agricultural species is longstanding, some progress was made by the Obama memorandum. Though the memorandum was also codified under "Agriculture", it leveraged its power to address the economic, social, and ecological value of honeybees. 
The framing of honeybees in national policy also directly impacts beekeepers. Not only are honeybees and beekeepers viewed primarily in an agricultural context, policy supports focus on them as only a commercial system. Other than the Obama Memorandum, the law solely focuses on commercial beekeepers, offering them honey price support and emergency funding. Protection and assistance was framed through the lens of economics, with loans being the answer to the issues beekeepers face. This excludes the growing population of small-scale beekeepers who are working to sustain honeybee populations for a variety of reasons other than commercial gain or agriculture.

For those commercial beekeepers who do provide their pollination services for agriculture and for small-scale beekeepers who wish to sell their honey, there is still the issue of foreign economic competition that needs greater policy attention. As Tammy Horn explains:

"One of the big issues has been honey imports have totally changed the ballgame, it's made it a really unfair market for beekeepers trying to compete" (Horn, personal interview, February, 23 2018)

One advantage domestic beekeepers could have over foreign competitors is better quality honey. However, there is no enforceable FDA standard for honey that beekeepers in the U.S.A can use to claim that domestic honey is better quality than the foreign product. Currently the FDA at best provides guidelines regarding food in general and labeling (Horn, 2018).

These trends have been ingrained into existing policy, but the Obama administration has used its power to shift the governmental framing of honeybees and 
beekeepers. The Obama memorandum and subsequent actions by the Pollinator Health Task Force reflect a shift towards a more holistic view of honeybee importance by considering the value of their ecosystem services, primarily pollination beyond that of agricultural crops. This reframing started with the Obama Administration recognizing the imminent impacts of losing our pollinators. In response to this imminent consequence, the Obama Memorandum reframed the threats to honeybee populations as not just a commerical issue, but one of agricultural sustainability. This resulted in a more urgent, diverse, and holistic policy response.

Additionally, the recent influx of new research priorities catalyzed by the Obama memorandum and solidified in the Pollinator Research Action Plan reflects a transition to concern over the honeybee populations themselves. This research, funded by publicprivate partnerships (PPPs), aims to establish the causes of hive failures. This goes beyond traditional policy mechanisms of simply providing emergency relief funding and honey price support. Other research aims to estimate and monetize the true value of pollination, invent new pesticide prevention practices and products, and better assess the risks of pesticide use. This change in focus empowers beekeepers of all scales, not just commercial businesses, with knowledge gained from research.

The use of PPPs to conduct research has been effective thus far due to increased grant availability and a variety of agreements with different levels of funding and goals (Pollinator Health Task Force, 2015 b). However, the PPPs described often follow a pattern of the public sector using its power to provide financial support or land that the private, non-governmental partner utilizes research. As mentioned, the Department of Agriculture has been budgeted for $\$ 10$ million a year for this research. This pattern of 
public support by financing private ventures also emerges in efforts to increase pollinator habitat, where 8 of the 11 programs implemented by the Department of the Interior and the United States Department of Agriculture offer either financial assistance or incentives to private partners (Pollinator Protection Task Force, 2016). One benefit for the public sector of establishing PPPs is the potential transfer of cost from the public to the private sector (Joseph, 2012; Roehrich, Lewis, \& George, 2014). However, the examples in the plan have the responsibility of cost staying within the public sector. This affects the longterm success of these pollinator protection projects because they are vulnerable to budget cuts if political leadership changes. For example, the current research budget established in Chapter 88 is effective through 2018, meaning that current political powers could limit or eliminate the funding for research, leaving private partners without a large source of financial support for continuing efforts to sustain pollinators.

Fortunately, there are research and pollinator habitat projects that rely more upon non-profits and volunteer work by citizens, like First Lady Michelle Obama's Million Pollinator Garden Challenge in partnership with the National Pollinator Garden Network (NPGN). The NPGN is "a non-partisan voluntary coalition" which provides a way for people to start gardens by supplying information, resources, and partnership opportunities. The NPGN partnered with the First Lady to create this challenge to register public and private gardens with the goal to obtain 1 million garden registrations (Pollinator Task Force, 2016). In this case, the private sector supports the costs of the website and network efforts through the member organizations of the network (currently about 50) and First Lady Michelle Obama used her power to increase visibility and encourage citizen engagement. 
This is similar to the Bee Informed Partnership, which is another example of a successful PPP related to the pollinator protection plan. This group began as a consortium grant supported financially by USDA grants with the core mission to reduce honeybee colony loss through research. Their research includes nation-wide annual surveying of beekeepers, sentinel apiary registration, and pest and disease survey data. The data and findings are open to the public and includes a user friendly interactive colony loss map and winter colony loss graphs for a variety of likely causes, empowering other researchers and beekeepers with the findings of a larger data set. As of 2014, the power dynamics shifted when Bee Informed became its own non-profit and began financially supporting itself with the public sector as a sponsor. This change in financing should make Bee Informed more resilient to withstanding changes in political power at the national level.

\section{$\underline{\text { National Discussion }}$}

President Obama's administration used its power to put forth the memorandum to establish research, Public-Private Partnerships, and a national pollinator protection strategy. It shifted policy emphasis with respect to honeybees from their being an agricultural species to providers of crucial ecosystem services and thereby empowered public entities to take on the responsibility of protecting pollinators in general. However, the policies regarding emergency protection are still financially and commercially driven. Firstly, these policies do not offer any sort of protection or incentive for small-scale beekeepers. This seems counterintuitive considering that the recent pollinator protection agenda and task force aim to establish habitat and more consistent best management practices across the country. Beekeeping is a best management practice and should be 
encouraged and incentivized alongside land management practices. One way to do this could be to provide a pollinator protector tax break for beekeepers that register their hives and participate in the nationwide surveillance program outlined in chapter 88 (7 USCS $\S$ 88-VII-5925). Secondly, the emergency relief fund does not specifically address theft and destruction of property by an individual, which is an issue that beekeepers are facing today when loaning hives to farms in different states (Andrews, 2018; L.A Times, 2018). To fix this issue the older acts should be revisited and amended to include modern concerns, possibly by consulting beekeepers.

The memorandum and subsequent Pollinator Partnership Action Plan rely heavily on the use of PPPs. Although there have been some successes thus far, continued governmental funding for necessary research and programs is critical to PPP success. This is not a sustainable model due to the periodic changes in power that results in changing funding policy. Instead the Million Pollinator Garden Challenge and the Bee Informed Partnership are examples of a potentially more resilient model. Both examples include the main private group being a non-profit with an extensive partnership network to support them. Both examples also continued to thrive after the reduction of the public sector's involvement, demonstrating the projects' resiliency. These examples suggest that using PPPs to start non-profit networks/projects and then transferring the power and responsibility of financial support to the PPP by government facilitating the non-profit to fund itself can be a successful model. 


\section{$\underline{\text { Kentucky State Policy }}$}

Unlike policy at the national level, the state of Kentucky has only one statute pertaining to beekeeping that has changed over time through amendments. In the Kentucky Statutes Title XXI “Agriculture and Animals" Chapter 252 "Apiaries”. The statute was originally enacted in 1942 and has undergone many changes including the majority of the statute being repealed, rewritten, and reenacted in 1986. In the rest of this section, I discuss what the statute regulated in the past, how the statute has been modified, what the statute regulates today, the governmental efforts besides policy, and the benefits and detriments of these changes.

\section{Established Disease Control}

By 1977, Kentucky had several regulatory restrictions on beekeeping and hive movement in place. At this time the major disease of concern was American Foulbrood, a fatal bacterial disease of honeybees. With the appearance of this disease in other countries, containing its spread became both a national and state level priority. On the state level, one concern was movement of bees. In Kentucky, a permit was needed by any beekeeper who wanted to move their bees or equipment into Kentucky with a fee penalty for non-compliance. Also, at that time registration and inspection of apiaries was required, with inspectors having right of entry and providing the mandatory inspection certificates. While both of these aimed to slow the spread of diseases, there was also the need for stopping the disease. During inspections any hive found to have American Foulbrood was to be quarantined and destroyed. Beekeepers were also allowed to use chemical treatments for prevention but not control (Martin et al., 1980:162-165). All of 
these treatments were to be carried out by the state apiarist and deputies. While these regulations increased power in the state apiarist's office, they also increased workload without commensurate increases in budget (KRS XXI-252.180 (1948)).

\section{Past Deregulation}

Since the statutes' establishment, several key parts of this statute have been repealed and amended, most of which occurred in 1986. Ironically, just as the spread of a pest called the Varroa mite began (Jones, 1958/2011), requirements and regulations for apiaries began to relax. These included the requirement of registering and of having a certificate of registration (KRS XXI 252.220,320 (1986)). However, some provisions were expanded or clarified, including the powers of the State Apiarist, and penalties for illegal importations. The State Apiarist could no longer enter any occupied dwelling without a warrant. Penalties were defined so that any person violating these statutes would be fined at most $\$ 100$ and have any honeybees or associated used equipment brought into the state of Kentucky confiscated and destroyed (KRS XXI-252.240, 990 (1986)). The roles of the state apiarist and deputies were also clarified to carry out the provisions described by having the powers of police officers (KRS XXI-252.180 (1986)). Over the years the process for quarantining were also amended to include the right for interested persons to receive notice of the quarantine and have a public hearing to allow said persons or their attorney to appear (KRS XXI-252.210 (1996)). 


\section{Kentucky Beekeeping Fund}

The Kentucky beekeeping statute was amended yet again in 2008, consolidating all the existing amended provisions and establishing the Kentucky beekeeping fund. Though it does reiterate the past provisions, much of these are optional to enact (denoted by the word "may" in the statute). For example, the statute states that the Commissioner of Agriculture may make and enforce rules, destroy infected bees hives, honey, and equipment, publish information about inspection/diseases, order beekeepers to report information, and establish a schedule of registration fees. The only "shall" in this statute concerns the duty to make known how money is received and utilized in the Kentucky Beekeeping Fund (KRS XXI-252.190 (2008)). The fund is a trust within the State Treasury and is administered by the Department of Agriculture for the use of helping the beekeeping industry in Kentucky, "particularly relative to small beekeepers", and states what can be received and how it can be used (KRS XXI-252.185 (2008)).

\section{Kentucky Pollinator Protection Plan}

Although Kentucky is in a current state of deregulation for beekeeping, there are efforts being made outside of the legislative arena to fulfill the goals set by President Obama's memorandum. The best and most current example of this is the Kentucky Pollinator Protection Plan (hereby referred to as "the KY Plan"). The KY Plan was released by the Kentucky Department of Agriculture in the summer of 2017 in response to President Obama's memorandum and the National Pollinator Protection Strategy from the Pollinator Health Task force (Pollinator Task Force, 2015 a). These national level policies called for states to work with the Department of the Interior and the Department 
of Transportation, to create state pollinator protection plans. Kentucky began to hold research and stakeholder meetings in response to these policies in 2015. In concurrence with the memorandum's suggested implementation of these policies through PublicPrivate Partnerships (PPPs), the Plan relies heavily on promoting stakeholder relationships.

The KY Plan begins much like the national memorandum and the strategy, by introducing the potential threats to the sustainability of managed pollinators. However, the introduction recognizes that a broader historical and ecological view is needed to develop the potential of the honey industry in Kentucky. It concludes with:

“...Kentucky is well positioned to reclaim a leadership role in apiculture if the goals of this plan are implemented. This plan acknowledges unmanaged pollinators are equally sensitive to land use changes...” (Horn 2016, p. 5)

Although the KY Plan starts with a focus on honeybee related industries, its goals and actions vary. This reflects the diverse interests of stakeholders represented. The 29 different stakeholders listed in the KY Plan consist of companies, associations, state government, federal government, clubs, and universities. Beekeepers were represented by the Kentucky State Beekeepers Association. As Tammy explained, the KY Plan's effectiveness relies on the PPPs between these stakeholders. This is also reflected by the KY Plan's main goal to "bring awareness to the issues faced by all parties and find ways for everyone to be part of solutions". Therefore, in making the KY Plan, the process 
consisted of public meetings from 2015 to 2017 where stakeholders contributed to the KY Plan's content and goals, while keeping the plan amenable and voluntary.

The KY Plan outlines four goals to be achieved by these public-private partnerships: 1) encouraging Best Management Practices (for beekeepers, pesticide applicators, landowners/growers, and governmental agencies), 2) increasing pollinator habitat, 3) enhancing communication, and 4) improving and maintaining extension \& outreach. The first two goals are given the most attention in the KY Plan. However, the best management practices are "intended to be voluntary" and the goal of increasing pollinator habitat relies on government or voluntary action. The other two goals consist of partial listings of opportunities to achieve them.

Ultimately, all of the goals are intended to be met by establishing PPPs amongst the stakeholders. The KY Plan itself does not outline future PPPs and does not mention any private sector commitments other than investments in pollinator research and soybean research from the Kentucky Soybean Promotion Board and Kentucky Soybean Association. The KY Plan concludes with restating the importance of having "a diverse agriculture sector" and "reviving Kentucky's once-dominant honey production industry". In addition it states:

"This document reflects policies to enhance communication among beekeepers, chemical applicators, and landowners; and to consider increasing habitat with a goal toward responsible economic development as well as providing nutrition and shelter" (Horn, 2017, p. 17) 
As Tammy explained in her interview, the Kentucky Pollinator Protection Plan was intended to initiate and enhance communication between the stakeholders and to synthesize information so that the stakeholders would have the networking, information, goals, and ideas needed to form future PPPs for the sake of sustaining pollinators.

\section{$\underline{\text { State Analysis }}$}

\section{Statute}

As with any policy, Kentucky statute 252 reflects the balance between requirements and enforcement. The original statute may have been driven by the economic power of commercial beekeeping, which characterized the industry when the statute was first enacted. The "Beekeeping in the United States" agricultural handbook from the USDA provides information regarding the industry at this time (Martin et al., 1980). The requirements prior to the 1986 repeals were strict, as with many states at the time, so as to prevent disease from spreading. But the reason for the repeals might have reflected the increased economic value of honey and therefore increased political power of commercial beekeepers. The handbook also has the statistics on bees and honey reported by USDA's Economics, Statistics, and cooperative Service. From 1967 to 1977, the total value of honey in the United States almost tripled despite the decrease in the number of colonies and honey production. This reduction in supply in relation to the existing demand caused the price per pound of honey to increase by a factor of 3.5 . Beeswax also followed this trend with its total revenue doubling and its price per pound tripling despite decreased production (Martin et al., 1980, p. 180-181). With this increased price of honey and beeswax, the 1986 repeals may have been intended to 
further stimulate the economic growth of the honeybee industry to meet consumer demand.

This period of deregulation led to the current statute and has likely encouraged the growth of "hobbyist beekeepers" in Kentucky. This group is defined as beekeepers who keep a small number of hives for various reasons including earning income or trading outside of the formal marketplace economy, helping slow down the decline of pollinators, pollinating their gardens, and enjoying beekeeping itself (Jones, 1958/2011). One reason this group has grown is the lack of regulations, including required registration and inspection. The lack of registration requirements and hive inspections has meant that anyone can become a beekeeper just by purchasing the necessary equipment from a commercial or local supplier. This growth in hobbyist beekeepers has impacted legislation as seen by the 2008 amendment to establish the beekeeping fund with the small beekeeper in mind (KRS XXI-252.185 (2008)).

Due to this influx of hobbyists working outside of the formal economy, the ability to register beekeepers and enforce previous statutes thoroughly would have become a challenge to the state apiarist and deputies due to lack of labor and other resources. However, the current statute uses the word "may" in the amendment when describing the duties of the State Apiarist and deputies (KRS XXI-252.190 (2008)). The use of the word means that while the State Apiarist and deputies have power, they are not required, to enforce the statute by destroying infected hives, ordering beekeepers to report information, or establishing a schedule of registration. Currently, beekeepers can voluntarily register their own hives and/or request an inspection by the State Apiarist. However, loss of required registration means the inability to accurately track Kentucky's 
beekeepers, and by extension their honeybees, and loss of required inspection results in the inability to track the spreading of diseases accurately. This information is needed to address the threats to honeybees and the overall sustainability of our pollinator-dependent agroecosystems.

\section{Kentucky Pollinator Protection Plan}

Though not official law, the Kentucky Pollinator Protection Plan (the KY Plan) also follows the state policy trend of using industry-focused, voluntary action in the form of public-private partnerships (PPP) to support a societal goal once considered solely in the governmental domain. The KY Plan has a diverse stakeholder base and has scientific research to inform their goals. Completing a coherent plan with so many stakeholders and interests is a success in it of itself. It gives room for people to take responsibility for the sustainability of Kentucky's pollinators rather than forcing reluctant participation. However, the success of the plan lies ultimately in the formation and actions of PPPs.

PPPs have increased in usage in the U.S.A at both national and local scales (Roehrich et al., 2014), but there is debate as to whether PPPs actually accomplish what they set out to do. Proponents argue that PPPs can encourage innovation, realize longterm savings, and transfer risk to the private sector. Critics argue that PPPs provide inconsistent results, transfer negotiating power to private entities thereby resulting in agreements that limit government flexibility, and still encumber tax payers with funding projects through other means (Joseph, 2012; Roehrich et al., 2014). A recent review of PPPs analyzed 1419 papers to offer a more broadly based appraisal of the advantages and disadvantages of PPPs (Roehrich et al., 2014). The authors summarized their findings by 
stating that PPPs differ in this regard and lie along a spectrum of varying public and private responsibility versus distribution of risk. They also note that methods for measuring the success of a PPP are ambiguous or unmentioned in the publications, with most relying on case studies. However, the authors made suggestions as to how to improve a PPP's chances of success. Some of these include creating projects with minimal financial risk, empowering non-governmental entities (particularly non-profits) through robust stakeholder involvement, allowing room for innovation and creativity, and maintaining good communication among partners. Fortunately, the KY Plan exhibits all of these attributes. Though success is possible, there are still challenges to be face by the KY Plan efforts, including the possibility that PPPs will not form, that relationships with stakeholders may become damaged, and that progress may be unquantifiable.

\section{$\underline{\text { State Discussion }}$}

The shift to beekeepers opting into registration and inspection is practical in light of the sheer amount of beekeepers, their varying levels of being informed, and the constraints on labor and funding. The current opt-in registration and inspection also empowers citizens to become beekeepers by not burdening new beekeepers with legal responsibilities. However, without registration gathering of data from beekeepers on hive health and other conditions becomes vital in trying to analyze the interactions in the managed honeybee system. Currently beekeepers are encouraged to answer surveys regarding their hive loss and health and to have their hives inspected, but there is a low response rate (Bee Informed, Horn, personal interview, February 23, 2018). 
I suggest that registration can still be voluntary but more effective even under present fiscal and governmental hiring constraints for assessment and reporting programs. One option could be to use social ties to recruit beekeepers to register their hives while keeping registration voluntary. This could be done by forming PPPs between the State Apiarist, presidents of bee associations/clubs, and beekeeping supply companies to encourage the participation of associations and registration of hives. To incentivize registration, a supply company could offer discounts to members of a beekeeper association. Associations and supply companies could also offer to register hives for beekeepers since both entities already collect personal information. For example, Kelley Bee Company in Kentucky could offer a discount for Kentuckiana Beekeeper Association members. Since they collect information for shipping purposes, they could have an opt-in option for the company to register purchased hives for the customer. This PPP could benefit beekeepers because they would be involved with a social group to receive advice and assistance through being a member of an association, get discounts for needed supplies, and be registered without additional hassle. This would benefit beekeeper associations because beekeepers would have incentive to join and support the associations with membership fees. With more members the associations would have a larger knowledge base, and more people to volunteer for teaching, mentoring, outreach, and recruitment. The business would benefit by being advertised to the association members, and allowing them to track of changes in their consumer base of beekeepers. Lastly, the socio-ecological mutualism among people, honeybees and surrounding natural and agricultural ecosystems would benefit from increased pollination services for native 
plants and for crops, thereby improving the sustainability of the entire socio-ecological system.

For the Kentucky Pollinator Protection Plan there is the potential for PPPs to be successfully established so as to accomplish the goals set forth in the plan. The impact of the plan will be determined by those PPPs that could potentially form outside of the protection plan meetings. Therefore, the Kentucky Department of Agriculture should request that the stakeholders report on any successful or unsuccessful projects started because of the Kentucky Plan and their status. In subsequent years a progress report should be made with this information so that the effectiveness of the plan can be evaluated over time.

\section{$\underline{\text { Conclusions }}$}

The United States has a long history of beekeeping and due to its important ecosystem services and economic value there is a need to protect it. In light of the current challenges facing beekeepers today, it is important to examine the policies that regulate and support beekeeping. National and Kentucky State policy in the past has focused on fostering and supporting the commercialization of beekeeping for the honey industry. However, the National Pollinator Protection Strategy, recent policy changes, and research have focused on the value of honeybees as pollinators and have been striving to protect honeybee populations for this service. As the growth of small-scale beekeeping continues, we are seeing new attention paid to hobbyist beekeepers in Kentucky policy, but not the National Policy. To address the sustainability of pollination services, 
lawmakers should tailor policies towards small-scale beekeepers in addition to the commercial beekeeping industry. By supporting and empowering small-scale beekeepers through policy, we support an important subset of pollinator populations managed for the good of our ecosystems, food production, and economy.

In Chapter 3, I will more closely examine a subset of small-scale beekeepers in and near Louisville, Kentucky and explore factors that may influence the success of their hives and the honeybees that contribute to the sustainability of local natural areas and gardens in cities and suburbs 
CHAPTER 3

EXPLORING THE SOCIO-ECOLOGICAL DETERMINANTS OF

HONEYBEE (Apis mellifera) HIVE CONDITION AND COLONY GROWTH

IN THE LOUISVILLE METRO AREA

\section{$\underline{\text { Introduction }}$}

This chapter addresses the main question of: "How much impact do beekeeper characteristics and land use have on honeybee hive condition and colony growth?’. By determining the strength of these factors on hive success we can better support and sustain this socio-ecological system (SES) of beekeepers, their honeybees and their environment. I refer to this system as the managed honeybee socio-ecological system and the results of this SES include honeybee hive productivity and hive loss. It is well known that honeybee colony growth dynamics change from spring to early summer and then again from summer to autumn (McLellan, 1978; Oliver, $2015 \mathrm{a}, \mathrm{b}$ ). The variables that might affect those dynamics are likely to vary due to land use conditions (Garibaldi et al., 2011; Clermont, 2015; Lecocq et al., 2015; Lowenstein, 2015; Smart, Pettis, Euliss, \& Spivak, 2016) as well as to the management styles and activities of the beekeepers (Bee Informed, 2008-2017). Here we explore the extent to which honeybee colony growth might vary along an urban-to-rural land-use gradient in the Louisville Metro Area as well as the extent to which growth dynamics might be affected by beekeeper traits. For the remainder this chapter I will first explain what a socio-ecological system is, the methods used in this study to examine this system, the results of that examination, and a discussion of what can be concluded from this study. For the purposes of this study, this 
system is constrained to the local scale. For the remainder this chapter I will first explain what a socio-ecological system is, the methods used in this study examine this system, the results of that examination, and a discussion of what can be concluded from this study.

\section{Theory}

The use of Socio-Ecological System (SES) frameworks emerged from the growing need to examine the interrelationships between human activities and the environment within the context of societal sustainability and resilience. The discipline of Urban Ecology has contributed greatly to this transdisciplinary field. These studies address questions regarding the impact of urban areas on natural processes, differences between urban areas and more natural areas, the diversity of life within urban areas, and the potential for integrating built and natural spaces by using theories from both natural and social sciences (Arnold \& Gibbons, 1996; McDonnell et al., 1997; Grimm et al., 2008; Pickett et al., 2011; Trammell \& Carreiro, 2011; White, Carreiro \& Zipperer, 2014; Clermont, 2015).

There are many different characteristics and ways to define a socio-ecological system. To generalize, a socio-ecological system is one that has social components (like human needs, desires, plans, governance, etc.) and natural components (like species, soil, water, air etc.) that rely upon and influence each other. For example, cities are socioecological systems in that there is ecological space, ecosystem services, and natural resources that the city depends, while also being the place where social constructs 
flourish like government, art, and knowledge (Pickett et al., 2011). This makes these systems very complex, multi-scalar, and requires creative and holistic thinking and problem solving to deal with challenges to human welfare.

The managed honeybee system can be characterized as a socio-ecological system because it consists of the natural components of honeybees, floral resources, pests, diseases and the social components of beekeepers, land-managers, laws pertaining to beekeeping, and government. This socio-ecological system of managed honeybees is currently facing the challenges of an increasingly developed environment and its management that interact with threats of disease and pests (Garibaldi et al., 2011; Clermont, 2015; Lecocq et al., 2015; Lowenstein, 2015; Smart et al., 2016). How beekeepers adapt to these challenges will also affect the success of these important pollinators that help sustain commercial and non-commercial food systems in cities, suburbs and surrounding rural areas. Therefore it is important to study the system to evaluate how resilient it is to development and to differences in land management and to find ways to improve its ability to face these issues. However, to evaluate the resiliency of this system we need to understand what factors significantly affect it. This study investigates the degree to which land-use and beekeeper characteristics and decision making affect the managed honeybee system in places with varying degrees of human occupation and land alteration (urban to rural areas). By determining which variables have the most impact we can suggest ways to increase the socio-ecological resilience of honeybee management systems. 


\section{$\underline{\text { Methods }}$}

\section{Beekeeper Survey}

The primary source of information for this assessment are the responses of surveyed beekeepers within the Louisville, Kentucky (KY) Metro area (Fig. 3, Appendix $1 \& 2$ ). The survey was made through Google Forms and copied into a MS Word file for distribution in paper form. They survey was approved by the University of Louisville Institutional Review Board (Study 16.1215) to be sent to local beekeepers. Beekeepers were recruited to take the survey through the Kentuckiana Beekeepers Association (KBA) via Facebook posts, emails, and announcements during KBA meetings from October 2017 through February 2018. The Kentucky State Beekeepers Association, Oldham County Beekeepers Association, and Shelby County Beekeepers Association were also asked to contact their members through email and/or Facebook. A few respondents with whom I had personal connections were contacted via email or Facebook. In order to recruit more responders a raffle drawing for a $\$ 25$ Kelley Beekeeping Supply Co. gift card was added as an extra incentive after IRB approval. The drawing winner was announced on Facebook and contacted.

Survey questions were designed to gather information about hive locations, hive types, hive health, beekeeper characteristics, and management practices from Spring to Fall of 2017. Therefore information regarding over-winter hive losses was not obtained. Appendix 1 consists of a copy of the survey questions. In compliance with IRB procedures, a consent letter was attached to emails and hard copies, posted on Facebook with the survey link, and was eventually incorporated into the survey itself. The survey 
responses are provided in Appendix 2, but the names and addresses of the respondents have been removed and replaced with codes. Using the answers for analysis required the overarching assumption that the respondents answered the questions accurately. In a few instances I had to re-contact some responders to clarify an answer. These clarifications are in Appendix 2, Table 4. If I was unable to contact and clarify their answer, I made assumptions to reach conclusions based on the beekeeper's responses to other questions.

\section{$\underline{\text { Response variables }}$}

I chose to measure productivity of the bee population in two ways, by growth in hive number and growth measured as the volume of deep frames in hives (Fig. 1). Hive counts were obtained by asking beekeepers how many hives they maintained at the start, middle and end of the beekeeping season (roughly the months of April, June and August), which corresponds to the plant growing season in this area and well documented periods of spring-to-summer colony growth and summer-to-fall colony decline (McLellan, Oliver, $2015 \mathrm{a}, \mathrm{b}$ ). However, the space available for bees to use for honey storage and for growing their population within a hive can also be determined by how many removable frames are in the hive (Fig. 1). Because there are different standard types of hives and frames sizes, beekeepers were asked to report what kind of hive they were using, the types of frames they were using, and the number of those frames being used by their bees for the three time points. This would permit calculations of frame volume per hive to compare in a standardized manner across different beekeepers as a measure of hive productivity. I also decided to use only deep frame counts to calculate the volume due to inconsistent answers from the beekeepers. Some beekeepers would report brood only and some would report brood and honey together. Therefore I was decided to focus on frames 
that typically have brood only (deep frames, D; Fig. 1). There were not enough beekeepers that harvested honey and accurately reported the amount harvested. As a result, I decided not to perform any analyses on beekeeper honey production, which is shown in the conceptual model in Fig. 2, because of inconsistencies in reporting. Due to these inconsistencies there were different sample sizes between the frames by beekeeper experience $(n=27,<1$ year $=6,1$ to 5 years $=13,5+$ years $=8)$ and frames by land use category $(\mathrm{n}=34, \mathrm{U}=12, \mathrm{~S}=12, \mathrm{R}=10)$.

Gains and losses in hive number over the season were also used as a measure of colony growth because it was more robust to reporting bias than frame counts. Hive number was determined by asking beekeepers how many hives they had at the beginning and end of summer and the reasons for any gain and/or loss of hives. From these answers and from re-contacting the beekeepers themselves, I was able to determine when the growth and losses occurred in order to calculate the number of hives for the middle of the season as well. Information gathered after the survey was taken is noted with the method of communication, and the additional information gathered (Appendix 2 Table 4). For statistical analysis, the following data were used: net hive growth over the entire season, gain, and loss. A "Gain" occurs when a beekeeper adds a new hive to their site. A "Loss" occurs when a beekeeper lost a hive at their site, and "Net Growth" is the difference between the end of season and beginning of season hive counts.

\section{$\underline{\text { Urban explanatory variables }}$}

Beekeepers who provided addresses that were within the study area (Fig. 3) and answered the survey completely were used for GIS and Statistical Analyses. Some 
beekeepers managed hives at multiple sites and gave addresses for each. The study area was determined by the extent of usable data for GIS analysis and proximity to Louisville.

Percent impervious surface has had a long history of use as a proxy variable for determining the impacts of varying degrees of urbanization on aquatic and terrestrial organisms and natural systems along urban-to-rural land-use gradients (Arnold \& Gibbons, 1996; Morse, Huryn, \& Cronan, 2003; Trammell \& Carreiro, 2011; Prescott \& Eason, 2018). Therefore, GIS analysis was conducted to determine the impervious surface percent using ArcMap 10.6, provided by the University of Louisville. Basemap data included state roads and county lines, provided by the Kentucky Geography Network. An impervious surface layer was created by merging together building, road, and pavement layers for Jefferson, Oldham, and Bullitt Counties provided by the Louisville/Jefferson County Information Consortium (LOJIC) database. Address points were given a $0.5 \mathrm{~km}$ buffer, since larger radii often overlapped between hive sites, and the study area impervious surface layer was then clipped to those buffers. Address points within Bullitt County did not have driveway, sidewalk, or parking lots in the impervious surface layers. This was corrected by tracing these features by on the LOJIC image layer consisting of aerial photography of the counties. Address points in Shelby and Spencer County did not have any accessible building, road casings, or pavement layers. To include these sites I traced all impervious features, as defined by LOJIC, using the same image layer.

Sites were then organized into different land-use categories: Urban (U), Suburban (S), and Rural (R) determined by surrounding impervious surface area (Table 1). Impervious surface area was divided by the total area to get an impervious surface 
percentage. The sites were then categorized by the impervious surface percentage as urban, suburban, and rural as $>30.00 \%, 12.00-29.99 \%$, and $<12.00 \%$, respectively. This is similar to the divisions used in a similar study (White et al., 2014). Three sites (HBF1, HBF2, and HBF3) included in this study had addresses that were unable to be disclosed for the survey. The beekeeper was only able to confirm that they were in Oldham County and similar to his home location, which was provided. The impervious surface percentage was estimated to be the average of the other Oldham site locations so as not to lose three sites that were clearly in rural land use sites $(n=7$, mean $=9.74 \%)$.

\section{Beekeeper explanatory variables}

For the analysis involving beekeeper characteristics, multiple choice questions were asked on the survey regarding age, gender, race, and years of experience, as well as motivation(s) for beekeeping. Beekeepers were also asked if they had any problems with pests and if they treated or supplemented their hives in any way. Beekeepers that had hives within the study area were included in the analysis.

$\underline{\text { Statistical analyses }}$

Statistical analyses were performed using the XLSTAT program Version 2018.1. There were more sites $(n=37)$ than beekeepers $(n=30)$. Therefore, the urban explanatory variables and the beekeeper explanatory variables were tested separately.

All of the frame volume data were tested to determine if they fit assumptions of parametric tests, namely normally distributed data with stable variances. However, none of the data met these assumptions even after being log- or square-root transformed. 
Therefore, non-parametric tests were used. For categorical data the Kruskal-Wallis test was used and for impervious surface \% data the Spearman rank correlation was used.

We also decided to report data in hive counts, because there was some ambiguity in beekeeper reporting of frames for which some assumptions were used to provide data for analysis. Beekeeper hive count data was more dependable and robust because it did not require beekeepers to remember frame numbers retrospectively and distinguish Deep Frames from other frame types. Hive counts and their gains and losses are also tracked and recalled with greater accuracy by beekeepers. Since the datasets on gains and losses contained zero values, they were tested for their goodness of fit to a Poisson distribution. The gain data by site and by beekeeper was determined to not follow a Poisson distribution, and so the non-parametric Kruskill-Wallis test was used. The loss data by site and by beekeeper somewhat fit a Poisson distribution $(p=0.299, p=0.323$ respectively), therefore in addition to the Kruskall-Wallis test, the log-linear regression test was used.

\section{$\underline{\text { Results }}$}

\section{Summary data for hive sites and number}

At the start of the season, there were 66 hives distributed across 37 sites with a range of 1 to 5 hives per site. By mid-season there were 104 hives across 37 sites with 1 to 12 hives per site. By season's end, there were 89.5 hives with none to 11 per site. Of the 37 hive sites, 14 sites were categorized as urban, 12 sites were suburban and 11 sites were in rural for all three time points (Fig. 4). 
The average deep frame volume across all 34 hive sites used for this metric (12 in urban sites, 12 in suburban sites, and 10 in rural) was $135+/-95 \mathrm{dm}^{3}$ at the beginning, $264+/-207 \mathrm{dm}^{3}$ in the middle, and $245+/-222 \mathrm{dm}^{3}$ at the end of the plant growing season. Average deep frame volume across these sites grew by $+97+/-170 \mathrm{dm}^{3}$ from beginning to middle and lost volume by $-28+/-84 \mathrm{dm}^{3}$ from middle to end (Fig. 5).

Across all sites hive gain and loss there were 40.5 hives gained and 3 lost from beginning to middle, and 6.5 hives gained and 18 lost from middle to end.

\section{$\underline{\text { Summary data for beekeepers }}$}

Thirty beekeepers were included in the analysis for this study. Of these beekeepers 11 identified as female and 19 as male. Age distribution was as follows: 7 people were between 25-44 years old, 12 people were 45-54, and 11 people were over 55 . Only one beekeeper was a minority (African American), the rest were Non-Hispanic White or Euro-American. For experience categories 5 beekeepers had $<1$ year of experience, 15 had 1-5 years, and 10 had 5+ years (Fig. 6). Motivations for beekeeping included enjoyment $(n=23)$, helping with local pollination $(n=18)$, selling related products $(n=9)$, family tradition $(n=2)$, allergies $(n=3)$, and education $(n=1)$. The average frame volume across all 27 beekeepers grew by $161+/-195 \mathrm{dm}^{3}$ from beginning to middle and lost volume by $-22+/-104 \mathrm{dm}^{3}$ from middle to end of the season (Fig. 7). 


\section{Growth and Loss Patterns by Site}

\section{Growth}

Colony growth was measured in two ways, as growth in deep frame volume and gain in hive number. No statistical differences were found among land-use categories for beginning volume, middle season volume, or beginning to middle volume growth ( $\mathrm{p}$ $=0.5399, \mathrm{p}=0.3003, \mathrm{p}=0.9779$, respectively). Percent impervious surface did not explain the variation in deep frame volumes over time. There was no significant correlation between impervious surface and beginning deep volume (Spearman rho $=0.009)$, middle deep volume (Spearman rho $=0.069$, though is a trend $\mathrm{p}=0.134$ ), or beginning to middle deep volume growth (Spearman rho $=0.011)$ as seen in Fig. 8. There were also no significant differences in hive number growth by land use $(\mathrm{p}=0.653)$ or by impervious surface percent (Spearman rho $=0.008$, Fig. 8).

Therefore, for these hives across this particular urbanization gradient, it appears that neither impervious surface nor land-use categories offer explanatory power for growth of honeybee colonies calculated by using deep frame volume or by hive counts.

Loss

Colony loss was measured in two ways, as loss of deep frame volume and loss in hive number. No statistical differences were found among land-use categories for middle season volume, end season volume, or middle to end volume loss $(p=0.3003, p=0.3239$, $\mathrm{p}=0.5425)$. 
Percent impervious surface did not explain the variation in deep frame volumes over time. There was no significant correlation between impervious surface and middle deep volume (Spearman rho $=0.069$, though might be a trend $\mathrm{p}=0.134$ ), end deep volume (Spearman rho $=0.045)$, or middle to end deep volume loss (Spearman rho $=0.013$; Fig.

7). There were also no significant differences in hive number loss by land use $(p=0.315)$ or by impervious surface percent (Spearman rho $=<0.001$; Fig. 8).

Therefore, for these hives across this particular urbanization gradient, it appears that impervious surface nor land-use categories offer explanatory power for loss of honeybee colonies calculated by either deep frame volume or hive counts.

\section{Growth and Loss Patterns by Beekeeper}

\section{Growth}

Deep frame volume change over time was related to various beekeeper traits. Using the Kruskal-Wallis test, I found that experience level categories (0-1 years, 1-5 years, 5+ years, Fig. 7) exhibited marginal trends in explaining beginning deep volume (p $=0.131)$, middle deep volume $(\mathrm{p}=0.192)$, and beginning to middle deep volume growth $(\mathrm{p}=0.140)$. Experience category did not significantly explain the variation in hive gain $(\mathrm{p}$ $=0.438)$. Since experience was inconclusive, we next examined the motivations beekeepers have as a potential explanatory variable for honeybee colony growth. We placed beekeepers in two categories, whether a beekeeper sells or does not sell any hive products including their bees, queens, beeswax, and honey (Fig. 9). Beekeepers that sold products gained significantly more hives over the season $(\mathrm{p}=<0.001)$. This was the only statistically significant finding of this study. 
Experience category did not explain middle deep volume $(\mathrm{p}=0.192)$, end deep volume ( $p=0.283)$, or middle to end deep volume loss $(p=0.152)$. Hive loss during the season was also not related to experience level $(\mathrm{p}=0.976)$. Unlike growth, there was not any significant difference between sellers and non-sellers in hive losses ( $\mathrm{p}=0.288)$.

Though the results were insignificant, swarming behavior of the honeybees provided marginal information for explaining hive losses $(\mathrm{p}=0.118)$. This was included because swarming behavior correlates with risk behavior in beekeepers. Honeybees can swarm and leave the hive if the beekeepers are not careful in providing enough space for the bees to grow (Jones 1958/2011 p. 198-215; Oliver, 2015 c). Therefore by limiting that space for ease or extraction, the beekeepers risk having their colony swarm away. When gaining a swarm and adding it to their hive site, beekeepers risk their older hives being exposed to pests and diseases carried by the wild-caught swarm. However, pest presence (of small hive beetles, wax moths, or disease) did not explain hive losses (log-linear regression, $\mathrm{p}=0.437$ ) and was not correlated with the number of hives gained by catching swarms (Kruskal-Wallis, $\mathrm{p}=0.276$ )

\section{$\underline{\text { Discussion }}$}

\section{Frames vs Hives}

The lack of significance for land-use variables in explaining colony growth may be due in part to the overriding decisions made by beekeepers. Brood deep frames are usually consistent over time, within the sites, and across sites. Usually the beekeepers 
will choose to start with 1 or 2 deep frame boxes and keep those throughout the season, meaning that growth of the brood is limited by the decision of the beekeeper to add more frames or not. Filling a frame with honeybees as their population expands then reflects how well the colony can grow. Therefore, the main limitation to hive colony growth appears to be the beekeeper's decision to add frames, and is not likely to be a limited by conditions outside the hive, such as lack of floral resources or other land-use related factors. Other issues that would add variability to the dataset lies with the survey responses themselves, such as there being missing key information missing about the types of frames used (Appendix 2, Table 2 and Table 4). Some beekeepers included in this study did not keep accurate counts of how many deep frames were being used, instead assuming that all frames they put out were used, and would report rounded estimates (21/30 beekeepers reported this way). Therefore, the reported answers for deep frame counts were more dependent on the beekeeper's choices and rounding, and required several assumptions to work with. Beekeepers also didn’t consistently distinguish between types of frames and if they had brood, honey, or a mix. Therefore, although estimates of honey production were intended for this study, in future studies, I would suggest that questions either be more targeted about frame number or that attempts to use frame number not be made. Hive counts, on the other hand, were less variable and were more accurate because all beekeepers could recall the number of hives they had and also began with only 1-5 hives per site. This means that the loss or gain of a hive is more noticeable and the accuracy of beekeeper reporting was more dependable. 


\section{$\underline{\text { Land Use vs Beekeeper Variables }}$}

Most of the land use and beekeeper independent variables were unable to explain the variation in frame volume, hive count gains, and hive count losses. In some cases beekeeper experience category and management choices improved explanations concerning hive growth and losses. Experience categories provided slight trends in explaining deep frame volume variation. Motivation (selling or not selling honeybee products) significantly explained the variation in hive gains and is potentially provides a weak trend for explaining hive losses. Sellers contributed 34.5 of the 46.5 new hives gained throughout the season. Another variable that was based on decision making was swarm capture and loss over the season and was found to have a slight influence on hive loss.

Decisions about how much space to provide the honeybees, whether or not to harvest honey, and whether or not to provide food supplementation can affect the growth and food stores for the colony (Jones, 1958/2011, p. 217-234; Free \& Williams, 1971; Oliver, 2015 a, b, c; Bee Informed). This can translate into the ability of the colony to withstand disease, temperature change, and the winter season. Treatment and pest management decisions can affect the vulnerability of the colony to pest and diseases. The method of obtaining new hives can also affect both new and older hives at the site. Wild swarm capture is one of those methods, which 10 of the 34 beekeepers practiced. Wild swarm capture has the benefit of increasing the genetic diversity of the honeybees, endowing the colony with more favorable traits. However, there are risks to the colony as well, chief among them the risk of introducing pests and diseases into the hive and the potential for spread to other hives at the site. Therefore, while the built environment 
could potentially limit hive growth or exacerbate hive losses, it appears that beekeeper management decisions provide the best explanation for those response variables.

\section{$\underline{\text { Comparisons }}$}

Although most of the factors in the study did not significantly explain the variation in hive condition and growth, this study can still contribute to the growing knowledge of beekeepers. As mentioned previously, the Bee Informed Partnership is surveying beekeepers on the national scale. As with my study, there is a relatively low response rate by beekeepers 2017 (5114 for the nation, 49 for Kentucky vs. 30 beekeepers included in this study). However, Bee Informed has been surveying since 2008 , allowing them to combine several years of data. Some of their findings align with the findings of this study, including their conclusion that different motivations for beekeeping resulted in different percent hive losses over winter. As in this Louisville study, Bee Informed found that those that sold honey, hive products, or queens had the lowest losses $(35.6 \%, 34.2 \%, 29.3 \%$, respectively); while beekeepers motivated by personal use, helping the bees/environment, pollination, and allergies had the highest losses $(39.0 \%, 41.0 \%, 46.0 \%$, respectively). However, Bee Informed includes loss by operation size that focuses more on large commercial beekeepers. Their operation sizes include "backyard beekeepers" that have $<50$ colonies, "sideline beekeepers" that have 51 to 500 colonies, and "commercial beekeepers" that have more than 500 colonies. This categorization lumps together hobbyist beekeepers with small commercial beekeepers. Though the "backyard beekeepers" constituted $93.5 \%$ of the responses to Bee Informed, they only represented $4.8 \%$ of the managed colonies. The "backyard beekeepers" also had the highest average winter losses. Since this group has the highest number of 
beekeepers and the highest percent loss, it is important to research this group more thoroughly. This Louisville study filled in this gap by focusing more on the hobbyist beekeepers.

\section{$\underline{\text { Future Studies }}$}

Surveying beekeepers across multiple years and states by Bee Informed was successful in gathering enough data to have significant findings. However, their annual surveys still exhibited low response rates, an issue that needs to be dealt with if these data are to inform apicultural policy and management. Also, there is the issue of not getting accurate measurements from the beekeepers themselves. Therefore, more experimental studies where hives can be established in a standardized manner that maximizes frame installation and placed across different land gradients (e.g., climatic, land-use, eco-type) should be conducted to investigate the effects of different beekeeping practices and ecological gradients on hive growth and decline. This would contribute greatly in determining whether the best management practices put forth by the Kentucky Department of Agriculture actually improve honeybee colony health and productivity and increase methodological adaptation to changing environmental conditions.

\section{Conclusion}

Although the explanatory variables investigated in this study did not significantly explain the variation in different measures of hive productivity and turnover, namely frame volume, hive gain, and hive loss, there were some beekeeper variables that provided statistically weak trends that require follow up with a larger population of 
beekeepers and hives. Motivation for keeping bees significantly explained hive gain and was a potential trend in explaining hive loss. Risk behavior equated with the catching and losing of swarms was the strongest trend for hive loss. On the other hand, the impervious surface percent was the least significant variable tested to explain deep frame volume change, hive gain, and hive loss. Therefore, it appears that urban and suburban conditions do not necessarily limit honeybee colony growth and currently seem to provide enough resources for honeybees. These findings support the conclusion that beekeeper decisionmaking is a better predictor to explain hive productivity more so than land use. Therefore in order to improve the sustainability of our managed honeybee populations, we should focus on the beekeepers decision-making process, and informing them through additional research that determines the effectiveness of different hive management decisions. 


\section{CHAPTER 4}

\section{THESIS CONCLUSIONS}

The managed honeybee socio-ecological plays an important role in providing pollination services for our agricultural systems, and therefore is critical for sustaining our food security. The recent decline in honeybee populations related to the prevalence of colony collapse disorder and loss rate of hives over winter has resulted in the concern of losing our honeybee populations. Due to the valuable pollination service that honeybees provide, honeybee losses become a sustainability issue that has been acknowledged, but not fully acted upon at national and state levels. Currently we support honeybees by managing them with the practice of beekeeping. The resulting managed honeybee system exemplifies a system affected by the built, natural, and social environment. Ongoing research is needed to understand more about these effects and how strongly they impact the success of honeybee hives.

In this study we found that socio-political context influences beekeepers and their decision making through policy, research, and protection plans. The decisions that beekeepers make in this context impact their hives, potentially more so than land-use. These decisions affect honeybee hive distribution and condition, resulting in varying levels of honeybee population growth and loss.

Currently policy, research, and protection plans focus on fostering and supporting the commercialization of beekeeping for the honey industry. To address the sustainability of pollination services, policies, research, and the protection plans need to support smallscale beekeepers as well as the commercial businesses. Small-scale hobbyist beekeepers 
are currently not included in the Honeybee Act, Farm Bill, Supplemental Agricultural Disaster Assistance Act, or Emergency Assistance for Livestock, Honeybees, and FarmRaised Fish Program because these policies focus or require the beekeeper to be commercial. Even research by Bee Informed, which surveys for a variety of social and ecological factors, does not effectively distinguish hobbyist beekeepers as a unique group. Instead Bee Informed defines "backyard beekeepers" as having 1-50 hives; lumping together hobbyists and small commercial beekeepers. This lack of distinction between these groups could mean that differences between the motivations and management decisions of these groups are not recognized. Though the National Strategy to Promote the Health of Honeybees and Other Pollinators and the Kentucky Pollinator Protection Plan do take steps towards acknowledging the importance of hobbyists, the motivations and actions are focused on commercial interests. As a result commercial interests continue to shape these Public-Private Partnerships by influencing their goals and direction. Nonetheless, some (e.g., Bee Informed and the Million Pollinator Garden Challenge) have already had positive impacts by raising public awareness of our pollinator crisis, increasing pollinator habitat on public and private lands, and researching. However, current and future PPPs need to be more cautious of relying greatly on the public sector for funding since political commitment is likely to change over election cycles.

Although the language and actions of the national and state plans focus more on industrial beekeeping, their research and best management practices are useful for both commercial and hobbyist beekeepers. In particular, greater knowledge of the effectiveness of different hive management practices is important for all beekeepers to 
have. This is especially true for beekeeping practices, which are highly variable, even idiosyncratic. This is expressed in a saying within the beekeeping community: "If you ask five beekeepers a question, you'll get five different answers." (Lara Augustine, personal communication February 19, 2018). Although during this study I have found that you'll actually get seven different answers. Currently in Kentucky getting this information to beekeepers is done through the educational efforts of our State Apiarist, Tammy Horn and beekeeper associations and the establishment of best management practices in our Kentucky Pollinator Protection Plan. However, more controlled experimental studies involving standardized establishment and monitoring of hives are needed, particularly in urban and suburban areas where many hobbyists reside and where bees perform pollination services for natural areas, orchards and vegetable gardens. Obtaining clearer answers to definitively establish which practices are beneficial and which are harmful to managed honeybee populations can then improve the resiliency of the managed honeybee system specific to different parts of a state or region.

This study was unable to fill the need of such an experimental design, but it was able to contribute methods and information regarding potential variables that impact the growth and loss of honeybee hives in cities, suburbs and nearby rural sites. Although the potential predictor variables investigated in this study did not significantly explain the variation in frame volume, hive gain, and hive loss, we did find trends in the social variables, the strongest of which was the beekeepers desire to sell commercial products. Those that intended to sell products gained more hives over the season. This supports the conclusion that beekeepers decisions are a more important determinant of managed 
honeybee success than the location of the hives with respect to land use. Therefore the basis for beekeeper decision making needs to be investigated more closely.

The complex relationships between the natural, social, and built environment are the foundation of integrated systems that make up our society. Managed honeybees are a single part of a larger system of pollinators, humans, and the built environment, a system rich with social and ecological impacts. By understanding more about this system through the lens of political ecology and socio-ecological systems we become more equipped to improve the socio-ecological resiliency of this system, and ultimately the sustainability of our large agrosystems and smaller community-level gardens. Individuals have the ability to get involved and make well informed decisions to support these pollinators regardless of their location. The more individuals that contribute to this mission through beekeeping, wise land management, or policy making, the more likely our managed honeybees will continue to offer their ecosystem services for our collective and mutual benefit. 


\section{REFERENCES}

\section{Chapter 1}

Beaurepaire, A. L., Truong, T. A., Fajardo, A. C., Dinh, T. Q., Cervancia, C., \& Moritz, R. F. (2015). Host Specificity in the Honeybee Parasitic Mite, Varroa spp. in Apis mellifera and Apis cerana. Plos One, 10(8), e0135103.

Bush, M. (2004). The Practical Beekeeper: Volume 1. N-Star Publishing Co.

Clermont, A., Eickermann, M., Kraus, F., Hoffmann, L., \& Beyer, M. (2015).

Correlations between land covers and honey bee colony losses in a country with industrialized and rural regions. Science of The Total Environment, 532, 1-13.

Engel, M. (1999). The Taxonomy of Recent and Fossil Honeybees (Hymenoptera: Apidae; Apis). Journal of Hymenoptera Research, 8.2, 165-196.

Engel, M.S., Hinojosa-Diaz, I.A., Rasnitsyn,, A.P. (2009). A honeybee from the Miocene of Nevada and the biogeography of Apis (Hymenoptera: Apidae: Apini). Proceedings of the California Academy of Sciences,. 60.3, 23-38.

Garibaldi, L. A., Steffan-Dewenter, I., Kremen, C., Morales, J. M., Bommarco, R., Cunningham, S. A., \& Klein, A. M. (2011). Stability of pollination services decreases with isolation from natural areas despite honeybee visits. Ecology Letters, 14(10), 10621072.

Gallai, N., Salles, J., Settele, J., \& Vaissière, B. E. (2009). Economic valuation of the vulnerability of world agriculture confronted with pollinator decline. Ecological Economics, 68(3), 810-821.

Goulson, D. (2013). Neonicotinoids And Bees: What's All The Buzz?. Significance 10.3, 6-11.

Guez,, D. (2013). A Common Pesticide Decreases Foraging Success And Survival In Honeybees: Questioning The Ecological Relevance. Frontiers In Physiology, 1-7.

Hassan, R. M., Scholes, R. J., \& Ash, N. (2005). Ecosystems and human well-being: Current state and trends. Millennium Ecosystem Assessment Vol 1, Washington, D.C.: Island Press.

Henry, M., Béguin M.., Requier F., Rollin O., Odoux J.F., Aupinel P., Aptel J., ... Decourtye A.(2012). A Common Pesticide Decreases Foraging Success And Survival In Honeybees. Science 336.6079, 348-350.

Horn, T. (2006). Bees in America: How the honeybee shaped a nation. Lexington, KY: University Press of Kentucky.

Integrated Taxonomic Information System retrieved 4/4/2018 from https://itis.gov 
International Union for Conservation of Nature and Natural Resources (1980). World conservation strategy: Living resource conservation for sustainable development. Place of publication not identified

Mburu, J., Hein, J-L., Gemmill, B., Collete, L, (2006). Economic Valuation of Pollination Services: Review of Methods. Food and Agriculture Organization of the United Nations

Jones, R., \& Sweeney-Lynch, S. (2011). The beekeepers bible: Bees, honey, recipes \& other home uses. New York: Stewart, Tabori \& Chang. (Original work published 1958)

Juniper, T. (2013). What Has Nature Ever Done For Us? : How Money Really Does Grow On Trees. London, Profile Books, 108-117.

Kates, R. W., Parris, T. M., \& Leiserowitz, A. A. (2005). What Is Sustainable Development? Goals, Indicators, Values, and Practice. Environment. Science and Policy for Sustainable Development, 47(3), 8-21.

Kristine, S. M., Elizabeth, L. H., Melinda, R. K., Carlos, Z. M., Luciana, M., \& Dasak, P. (2013). Pathogens, Pests, and Economics: Drivers of Honeybee Colony Declines and Losses [Abstract]. EcoHealth, 10, 434-445.

Lecocq, A., Kryger, P., Vejsnæs, F., \& Jensen, A. B. (2015) Weight Watching And The Effect Of Landscape On Honeybee Colony Productivity: Investigating The Value Of Colony Weight Monitoring For The Beekeeping Industry." Plos ONE 10.7, 1-14.

Lemonick, M. D. (2009, March 01). Top 10 Myths about Sustainability. Retrieved April 02, 2018, from https://www.scientificamerican.com/article/top-10-myths-aboutsustainability/

Lowenstein, D. M., Matteson, K. C., \& Minor, E. S. (2015). Diversity of wild bees supports pollination services in an urbanized landscape. Oecologia,179(3), 811-821.

Lorenz, S., \& Stark, K. (2015). Saving the honeybees in Berlin? A case study of the urban beekeeping boom. Environmental Sociology, 1(2), 116-126.

Martin, E.C., E. Oertel, N. P. Nye, et al. (1980) Beekeeping in the United States. U.S Department of Agriculture, Agriculture Handbook No. 335, 2-7, 162-165, 180-182.

Matias, D. M., Borgemeister, C., \& Wehrden, H. V. (2017). Thinking beyond Western commercial honeybee hives: Towards improved conservation of honeybee diversity. Biodiversity and Conservation, 26(14), 3499-3504.

Mog, J. (2011, January 1). U of L Green Scene: What is sustainability? Retrieved April 02, $2018 \mathrm{http}: / /$ louisville.edu/uofltoday/campus news/uofl green scene what is sustainability

Putra, R. E., Agus D. P., \& Syayidah N. (2014). The Impact Of Insecticides To Local Honeybee Colony Apis Cerana Indica In Laboratory Condition. AIP Conference Proceedings, 1589, 385-388. 
Sponsler, D. B., \& Johnson, R. M. (2015). Honey bee success predicted by landscape composition in Ohio, USA. PeerJ, 3:3838

Thomson, D. (2004). Competitive Interactions Between The Invasive European Honeybee And Native Bumble Bees. Ecology, 85(2), 458-470.

Webster, T. (1977, revised 2013). Kentucky Beekeeping: A guide for beginners Cooperative Extension Program, Frankfort KY, 68- 79.

Wheeler, S. M. (2000). Planning for Metropolitan Sustainability. Journal of Planning Education and Research, 20(2), 133-145.

Williams, I. H., Corbet, S. A., \& Osborne, J. L. (1991). Beekeeping, Wild Bees and Pollination in the European Community. Bee World, 72(4), 170-180.

\section{Chapter 2}

Andrews, T. M. (2018, January 19). Vandals nearly destroyed an Iowa bee business. This week, police arrested two boys. The Washington Post.

Associated Press. (2018, January 17) 200,000 bees die when vandals topple hives, pour gas on them. Los Angeles Times.

Greenberg, J. B., \& Park, T. K. (1994). Political Ecology. Journal of Political Ecology, 1(1), 1-12.

Holdren, J. (2015) "Announcing New Steps to Promote Pollinator Health" The White House, Office of Science and Technology Policy

Horn, T. (2006). Bees in America: How the honeybee shaped a nation. Lexington, KY: University Press of Kentucky.

Horn, T. (2018, Febuary 23rd). Personal Interview

Horn, T. (2018) "FDA issues guidance on proper ways to label honey and honey products" Beelines, Kentucky Department of Agriculture.

Joseph, A. (2012, November 16). Public-Private Partnerships: A Double-Edged Sword. Harvard College Global Health Review.

Keil, R. (2003). Progress Report—Urban Political Ecology. Urban Geography, 24(8), 723-738.

Martin, E.C., E. Oertel, N. P. Nye, et al (1980). Beekeeping in the United States. U.S

Department of Agriculture, Agriculture Handbook No. 335, 2-7, 162-165, 180-182.

Obama, B. (2014) "Creating a Federal Strategy to Promote the Health of Honeybees and Other Pollinators" The White House, Office of the Press Secretary. 
Pollinator Health Task Force. (2015a). NATIONAL STRATEGY TO PROMOTE THE HEALTH OF HONEYBEES AND OTHER POLLINATORS. Washington, DC: The White House.

Pollinator Health Task Force. (2015b). POLLINATOR RESEARCH ACTION PLAN Washington, DC: The White House Retrieved

Pollinator Health Task Force. (2016). POLLINATOR PARTNERSHIP ACTION PLAN Washington, DC: The White House.

Robbins, P. (2012). Political ecology: A critical introduction (2nd ed.). Chichester: J. Wiley \& Sons, 11-24.

Roehrich, J. K., Lewis, M. A., \& George, G. (2014). Are public-private partnerships a healthy option? A systematic literature review. Social Science \& Medicine, 113, 110-119.

Thompson, Robert. (1993). The Fortune Encyclopedia of Economics, ed. David R. Henderson, New York: Warner Books.

United States Department of Agriculture, Farm Service Agency. (2017). Disaster Assistance Fact Sheet. Washington, DC

United States Department of Agriculture, Farm Service Agency. (2014). Marketing Assistance Loans and Loan Deficiency Payments for 2008 and Subsequent Crop Years 8LP (Revision 2). Washington, DC, 586-590.

United States Department of Agriculture, Farm Service Agency. (2018). Monthly CCC Honey Survey Price for Marketing Assistance Loans. Washington, DC

Laws

National United States Code- http://uscode.house.gov/browse.xhtml

7 USCS § 11-281 (1922)

7 USCS § 35A- 1446 (1949)

7 USCS § 115- 9092

7 USCS § 36-II-1531

7 USCS § 115-9081 (2012)

7 USCS § 11- 284

7 USCS § 36-I-1522

7 USCS § 77-4601-4613

7 USCS § 88-VII-5925

State Statute- http://www.lrc.ky.gov/statutes/chapter.aspx?id=38465 


\section{KRS XXI-252}

\section{Chapter 3}

Arnold, C. L., \& Gibbons, C. J. (1996). Impervious Surface Coverage: The Emergence of a Key Environmental Indicator. Journal of the American Planning Association,62(2), 243-258.

Clermont, A., Eickermann, M., Kraus, F., Hoffmann, L., \& Beyer, M. (2015). Correlations between land covers and honey bee colony losses in a country with industrialized and rural regions. Science of The Total Environment, 532, 1-13.

Free, J. B., \& Williams, I. H. (1971). The Effect of Giving Pollen and Pollen Supplement to Honeybee Colonies on the Amount of Pollen Collected. Journal of Apicultural Research,10(2), 87-90.

Garibaldi, L. A., Steffan-Dewenter, I., Kremen, C., Morales, J. M., Bommarco, R., Cunningham, S. A., \& Klein, A. M. (2011). Stability of pollination services decreases with isolation from natural areas despite honeybee visits. Ecology Letters, 14(10), 10621072 .

Grimm, N. B; Faeth, S. H; Golubiewski, N. E; Redman, C. L, Wu, J., Bai, X., Briggs, J. M. (2008) Global Change and the Ecology of Cities. Science 319, 756-760.

Jones, R., \& Sweeney-Lynch, S. (2011). The beekeepers bible: Bees, honey, recipes \& other home uses. New York: Stewart, Tabori \& Chang. (Original work published 1958)

Lecocq, A., Kryger, P., Vejsnæs, F., \& Jensen, A. B. (2015). Weight Watching and the Effect of Landscape on Honeybee Colony Productivity: Investigating the Value of Colony Weight Monitoring for the Beekeeping Industry. Plos One, 10(7), 1-14.

Lowenstein, D. M., Matteson, K. C., \& Minor, E. S. (2015). Diversity of wild bees supports pollination services in an urbanized landscape. Oecologia, 179(3), 811-821.

McDonnell, M. J., Pickett, S. T., Groffman, P., Bohlen, P., Pouyat, R. V., Zipperer, W. C., .. . Medley, K. (1997). Ecosystem Processes Along an Urban-to-Rural Gradient. Urban Ecosystems, 1(1), 21-36.

McLellan, A.R. (1978) Growth and decline of honeybee colonies and inter-relationships of adult bees, brood, honey and pollen. Journal of Applied Ecology 15, 155-161.

Morse, C.C., Huryn, A.D. \& Cronan, C. (2003) Impervious Surface Area as a Predictor of the Effects of Urbanization on Stream Insect Communities in Maine, U.S.A. Environmental Monitoring and Assessment 89(1), 95-127.

Oliver, R. (2015). Understanding Colony Buildup and Decline - Part 2. American Bee Journal, 155(3), 293-298. 
Oliver, R. (2015). Understanding Colony Buildup and Decline - Part 3. American Bee Journal, 155(4), 405-412.

Prescott, V. A., \& Eason, P. K. (2018). Lentic and lotic odonate communities and the factors that influence them in urban versus rural landscapes. Urban Ecosystems. 1-14.

Pickett, S., Cadenasso, M., Grove, J., Boone, C. G., Groffman, P. M., Irwin, E., . . Warren, P. (2011). Urban ecological systems: Scientific foundations and a decade of progress. Journal of Environmental Management,92(3), 331-362.

Smart, M. D., Pettis, J. S., Euliss, N., \& Spivak, M. S. (2016). Land use in the Northern Great Plains region of the U.S. influences the survival and productivity of honey bee colonies. Agriculture, Ecosystems \& Environment, 230, 139-149.

Trammell, T. L., \& Carreiro, M. M. (2011). Vegetation composition and structure of woody plant communities along urban interstate corridors in Louisville, KY, U.S.A. Urban Ecosystems, 14(4), 501-524.

White, R. J., Carreiro, M. M., \& Zipperer, W. C. (2014). Woody plant communities along urban, suburban, and rural streams in Louisville, Kentucky, USA. Urban Ecosystems, 17(4), 1061-1094.

Winston, M.L. (1980) Swarming, afterswarming, and reproductive rate of unmanaged honeybee colonies (Apis mellifera). Insectes Sociaux 27(4), 391-398. 


\section{$\underline{\text { Table }}$}

Table 1 Results of the GIS analysis of the $0.5 \mathrm{~km}$ buffer around the study sites. Impervious surface area percent was calculated by divided the impervious surface area by the total area of the $0.5 \mathrm{~km}$ buffer. Sites were then assigned Rural, Suburban, Urban according to the impervious surface area percent.

\begin{tabular}{lll}
\hline Name Code & Impervious Surface Area (\%) & Land Use Category \\
\hline CA & 4.73 & $R$ \\
DR3 & 2.58 & $\mathrm{R}$ \\
HBF1 & 9.74 & $\mathrm{R}$ \\
HBF2 & 9.74 & $\mathrm{R}$ \\
HBF3 & 9.74 & $\mathrm{R}$ \\
HBF4 & 11.72 & $\mathrm{R}$ \\
ME & 3.00 & $\mathrm{R}$ \\
RF & 1.15 & $\mathrm{R}$ \\
TL & 2.16 & $\mathrm{R}$ \\
UK2 & 3.02 & $\mathrm{R}$ \\
AC & 16.83 & $\mathrm{~S}$ \\
BR & 22.43 & $\mathrm{~S}$ \\
BW & 18.44 & $\mathrm{~S}$ \\
DR1 & 27.63 & $\mathrm{~S}$ \\
DR2 & 13.58 & $\mathrm{~S}$ \\
LD & 21.15 & $\mathrm{~S}$ \\
RS & 17.40 & $\mathrm{~S}$ \\
SB & 25.62 & $\mathrm{~S}$ \\
SC & 12.69 & $\mathrm{~S}$ \\
TS1 & 23.82 & $\mathrm{~S}$ \\
TS2 & 16.64 & $\mathrm{~S}$ \\
WW & 24.85 & $\mathrm{~S}$ \\
DL & 43.06 & $\mathrm{U}$ \\
DS & 57.91 & $\mathrm{U}$ \\
JC1 & 49.15 & $\mathrm{U}$ \\
JC2 & 35.40 & $\mathrm{U}$ \\
JD & 66.67 & $\mathrm{U}$ \\
JM & 43.92 & $\mathrm{U}$ \\
KJ & 41.87 & $\mathrm{U}$ \\
KT & 47.85 & $\mathrm{U}$ \\
LA & 41.23 & $\mathrm{U}$ \\
PW & 37.42 & $\mathrm{U}$ \\
RYS & 58.36 & $\mathrm{U}$ \\
UK3 & 33.71 & \\
\hline & &
\end{tabular}




\section{$\underline{\text { Figures }}$}

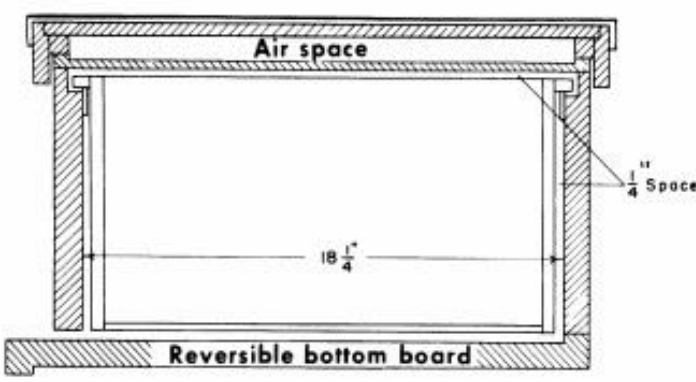

CROSS SECTION OF HIVE BODY ANO FRAME

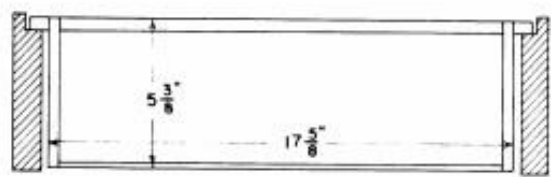

CROSS SECTION OF SHALLOW SUPER

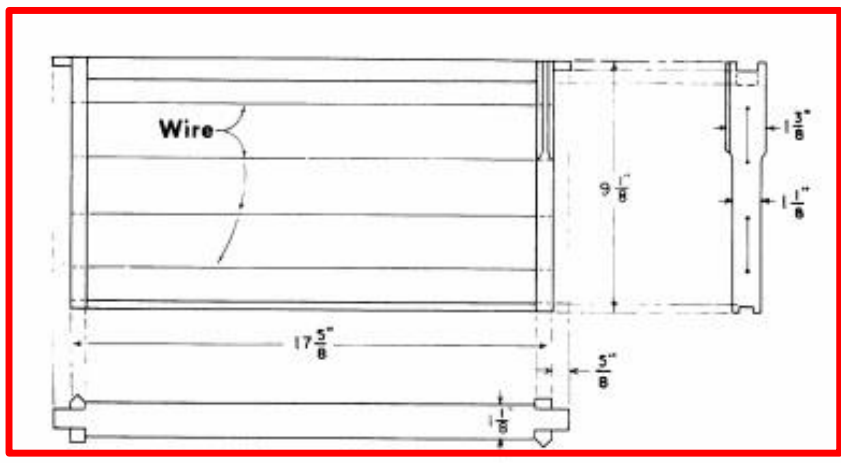

SIDE, END, AND TOP ELEVATION OF FRAME

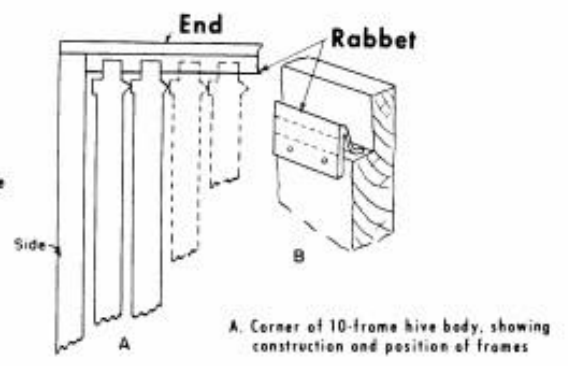

8. Port of end of hive bady, sheming robbet, which shoold be mode of tin of galvenized
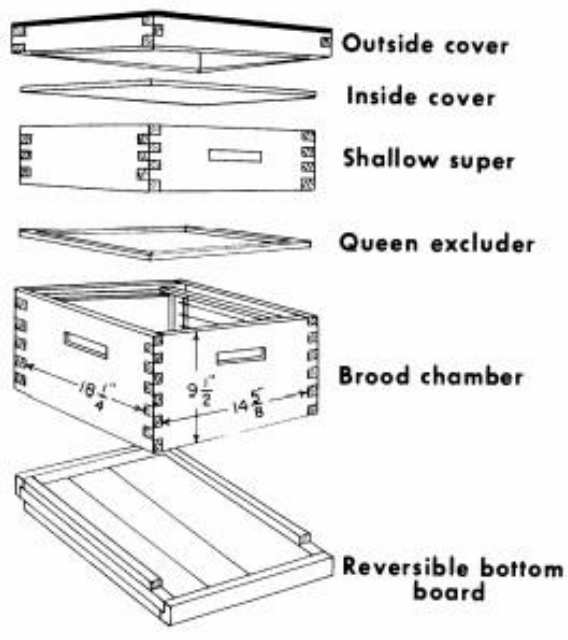

$\mathrm{BN}-30052$

Fig. 1. Diagram of a Langstroth Hive provided by the Beekeeping in the United States United States Department of Agriculture (1980). The dimensions of the deep frame is boxed in red and was used to calculate Deep Frame Volume. 


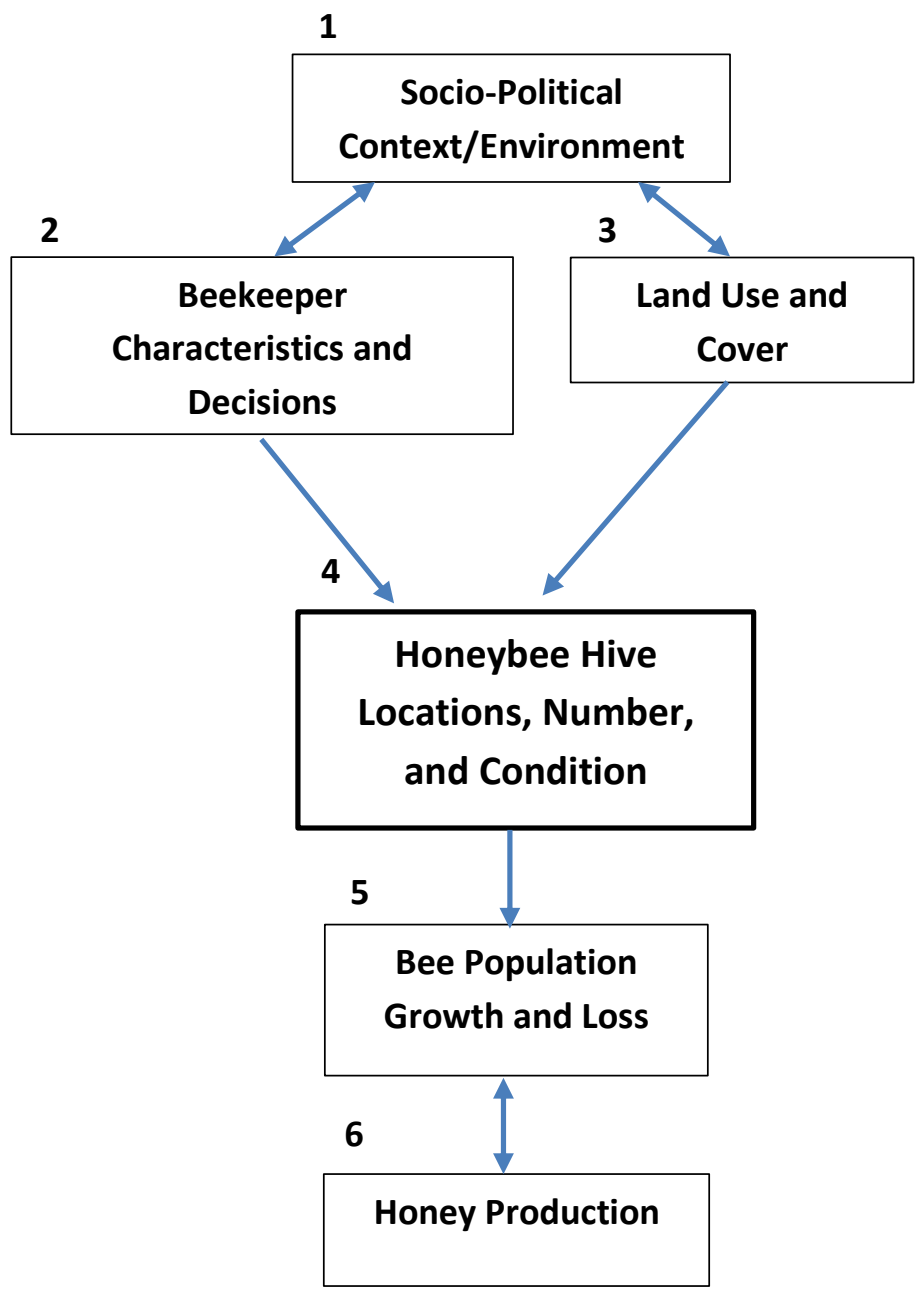

Fig. 2. Framework used in this thesis that shows how the variables in this study interact and impact honeybee hives. Chapter 1 describes the model. Chapter 2 focuses on box 1 and Chapter 3 focuses on boxes 2, 3, 4, and 5 . 


\section{Location of Hive Sites}

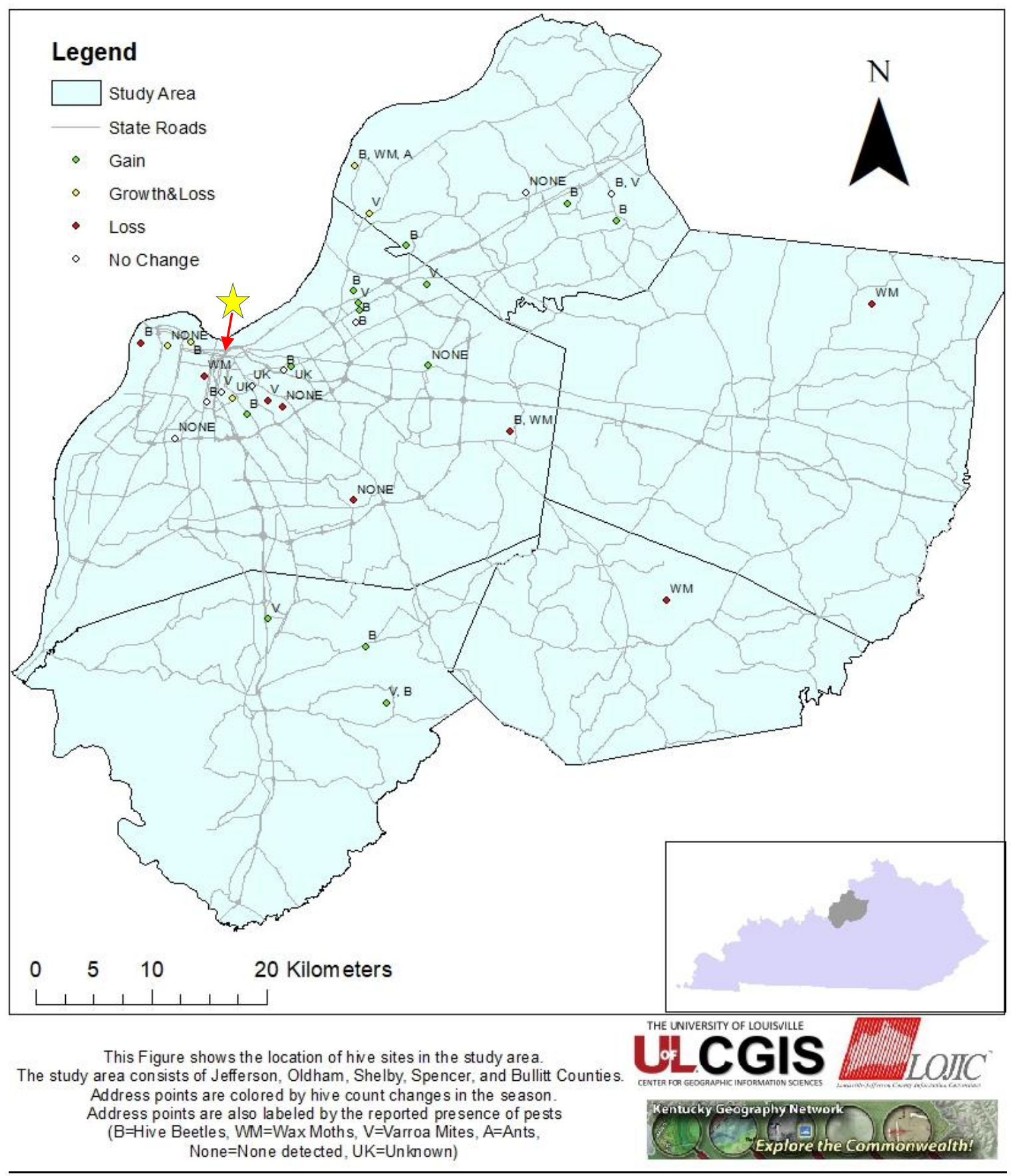

Fig. 3 Map of study locations in the Louisville Metro Area encompassing Jefferson, Oldham, Shelby, Spencer, and Bullitt Counties. Star shows location of downtown Louisville. Inset map shows study area within the entire state of Kentucky. Inset map shows study area within the state of Kentucky. The scale refers to the Metro Area map. 


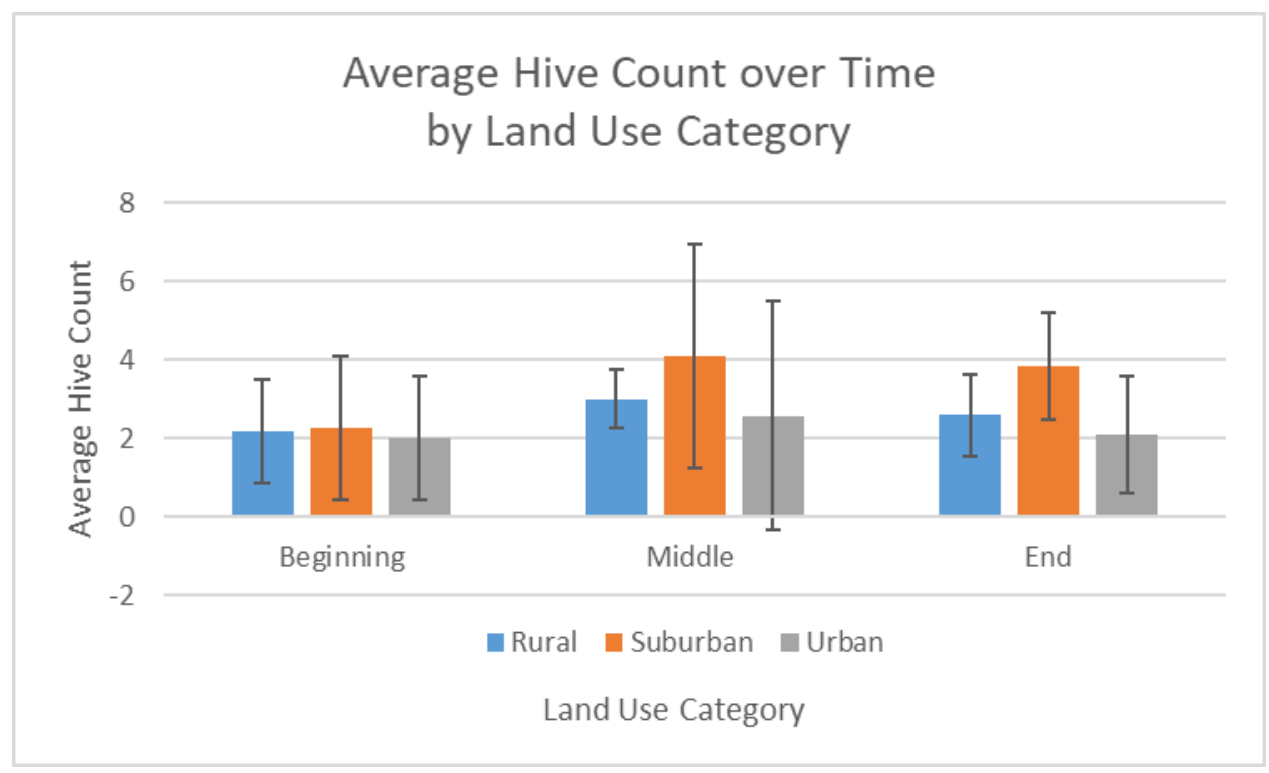

Fig. 4. Average hive counts per site in the Rural, Suburban, and Urban areas at the beginning (March), middle (June) and end (October) of the plant growing season in 2017. $\mathrm{n}=11$ hive sites in rural, $\mathrm{n}=12$ in suburban, $\mathrm{n}=14$ hive sites in urban areas. 


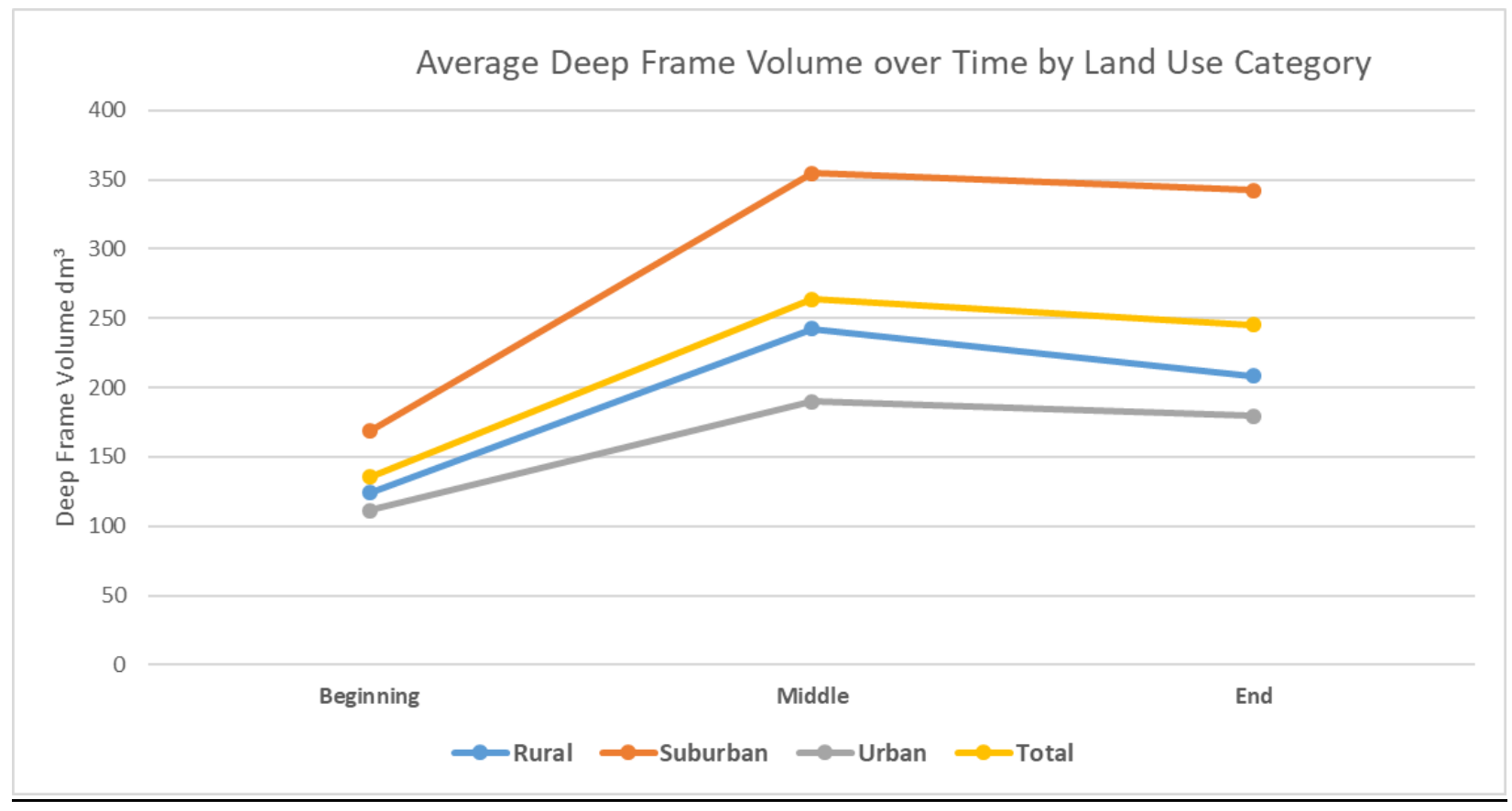

Fig. 5. Change in average deep frame volume from the beginning, middle, and end of the season. The graph shows the total average and the Rural, Suburban, and Urban averages. All showed the pattern of growth and then loss over the season. There were no significant differences between the land use categories. 


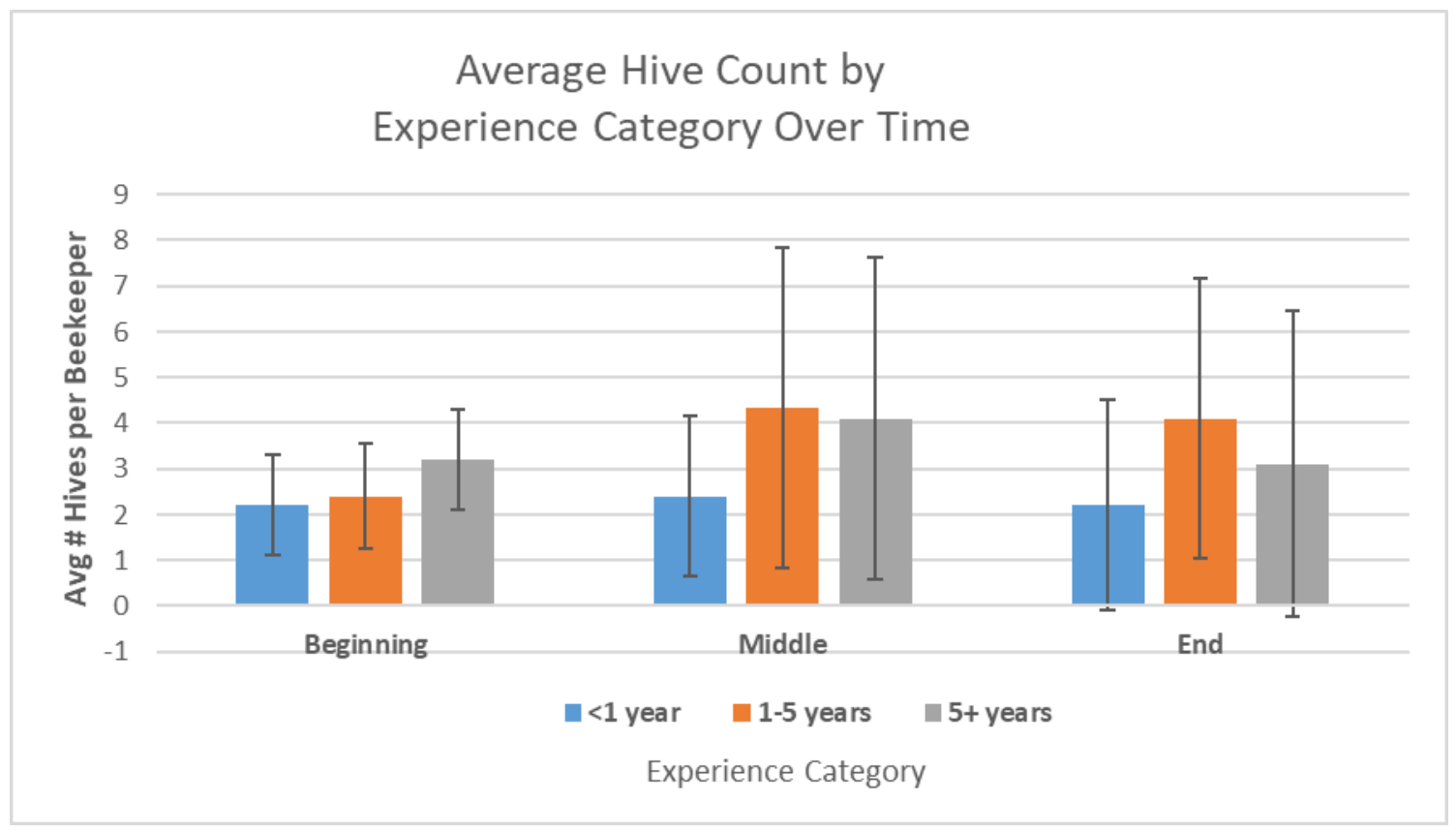

Fig. 6. Average number of hives kept by beekeepers of varying beekeeping experience levels ( $<1$ year, $1-5$ years, 5+ years) at the beginning, middle and end of the plant growing season. There were no significant differences by experience levels for any of the time points. $n=5$ beekeepers with $<1$ year, $n=15$ beekeepers with $1-5$ years, $n=10$ beekeepers with $5+$ years. 


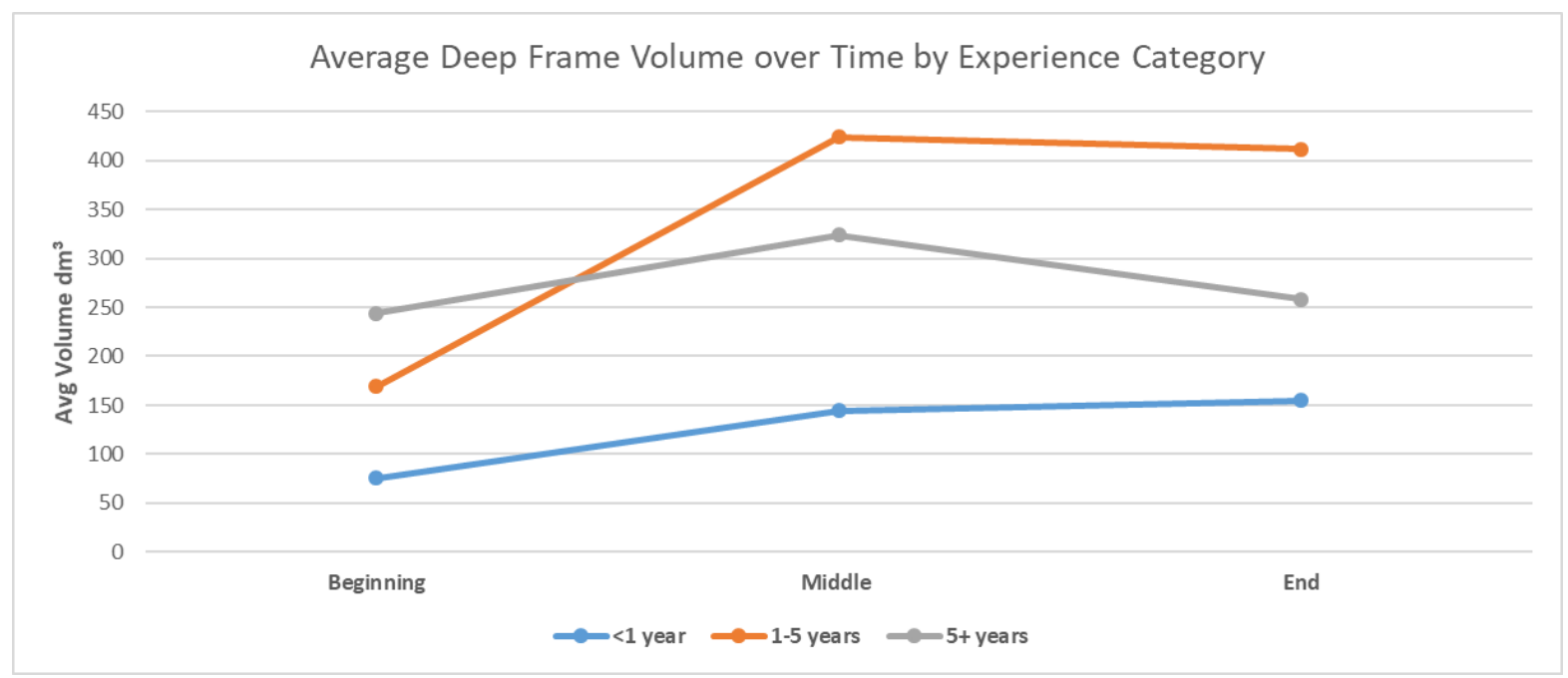

Fig. 7. Change in average deep frame volume from the beginning, middle, and end of the plant growing season. The graph shows the averages for the experience categories: < 1 year, 1-5 years, and 5+ years. All showed the pattern of growth and then loss over the season but were not statistically different by experience level. 

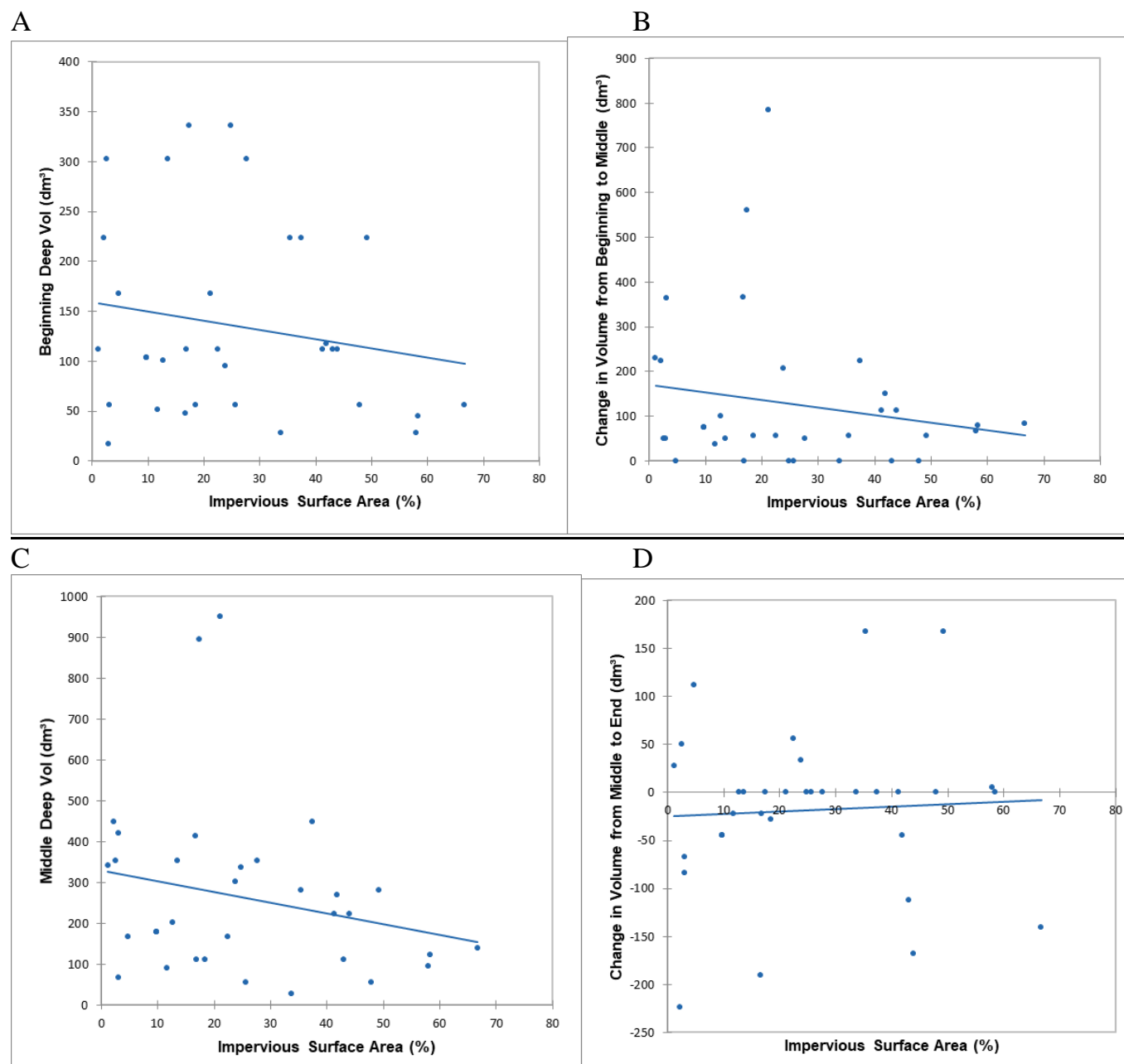

\section{$\mathrm{D}$}

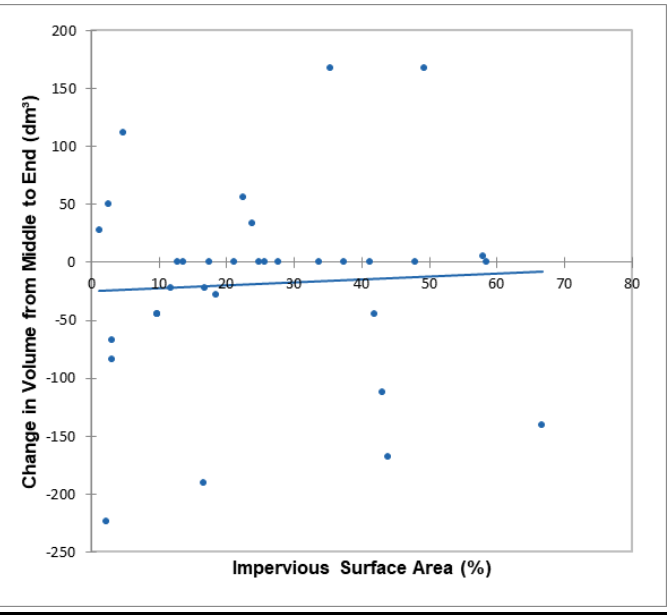

F

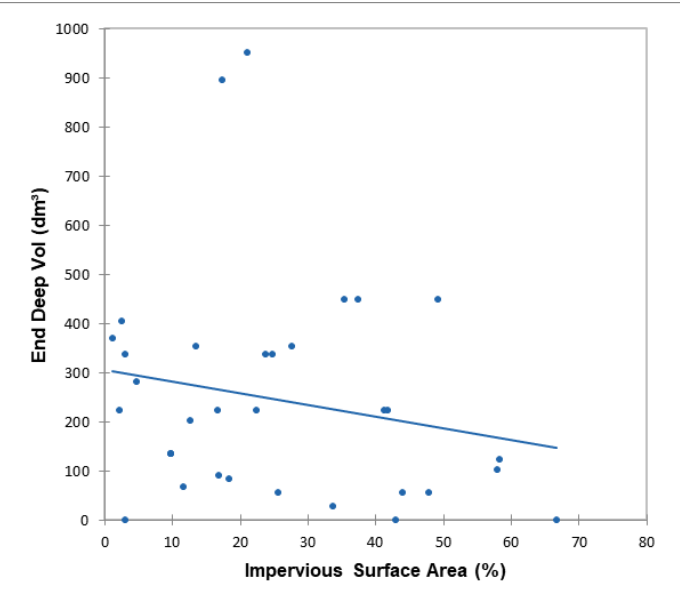

Fig. 8. Relationships between impervious surface percent and deep frame volumes for beginning (A), change from beginning to middle $(\mathrm{B})$, middle $(\mathrm{C})$, change from middle to end (D), and end (F) of plant growing season. Spearman rho correlations for each of the response variables were not statistically significant. 
A

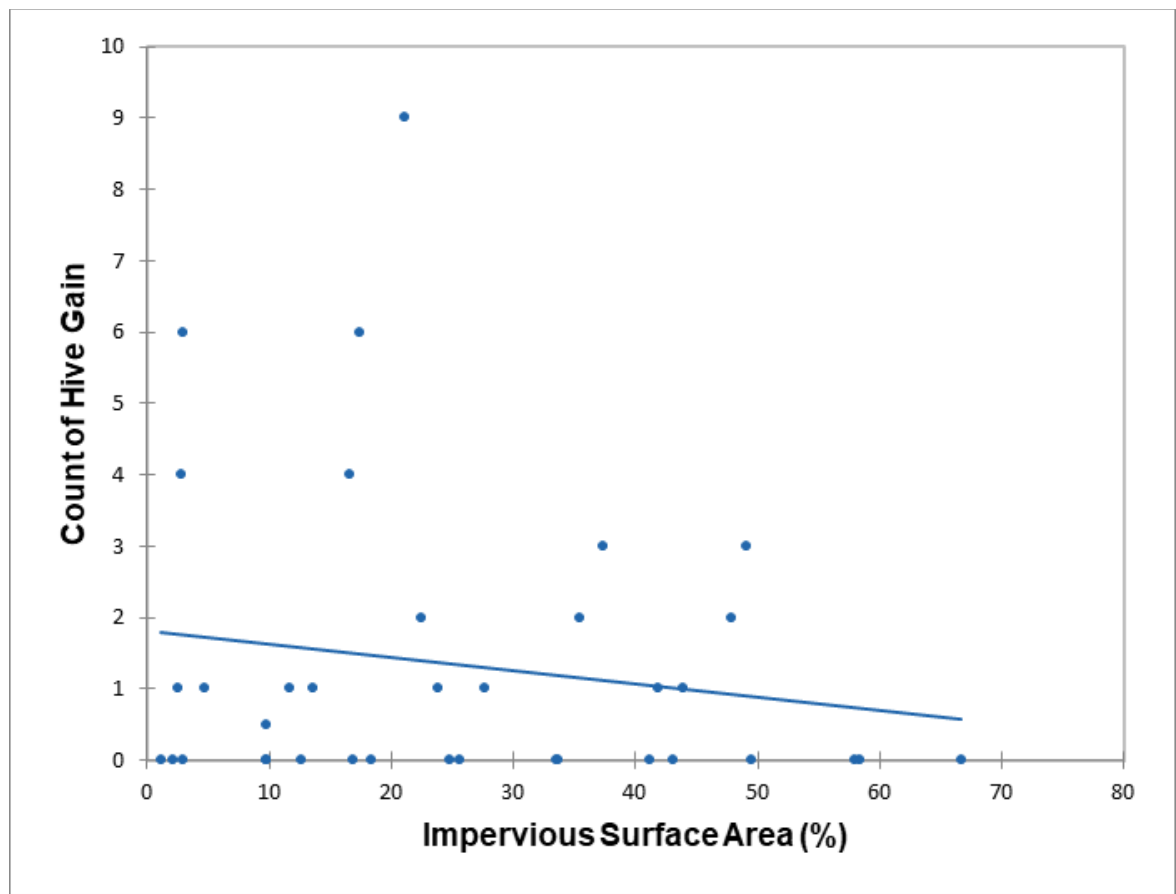

B

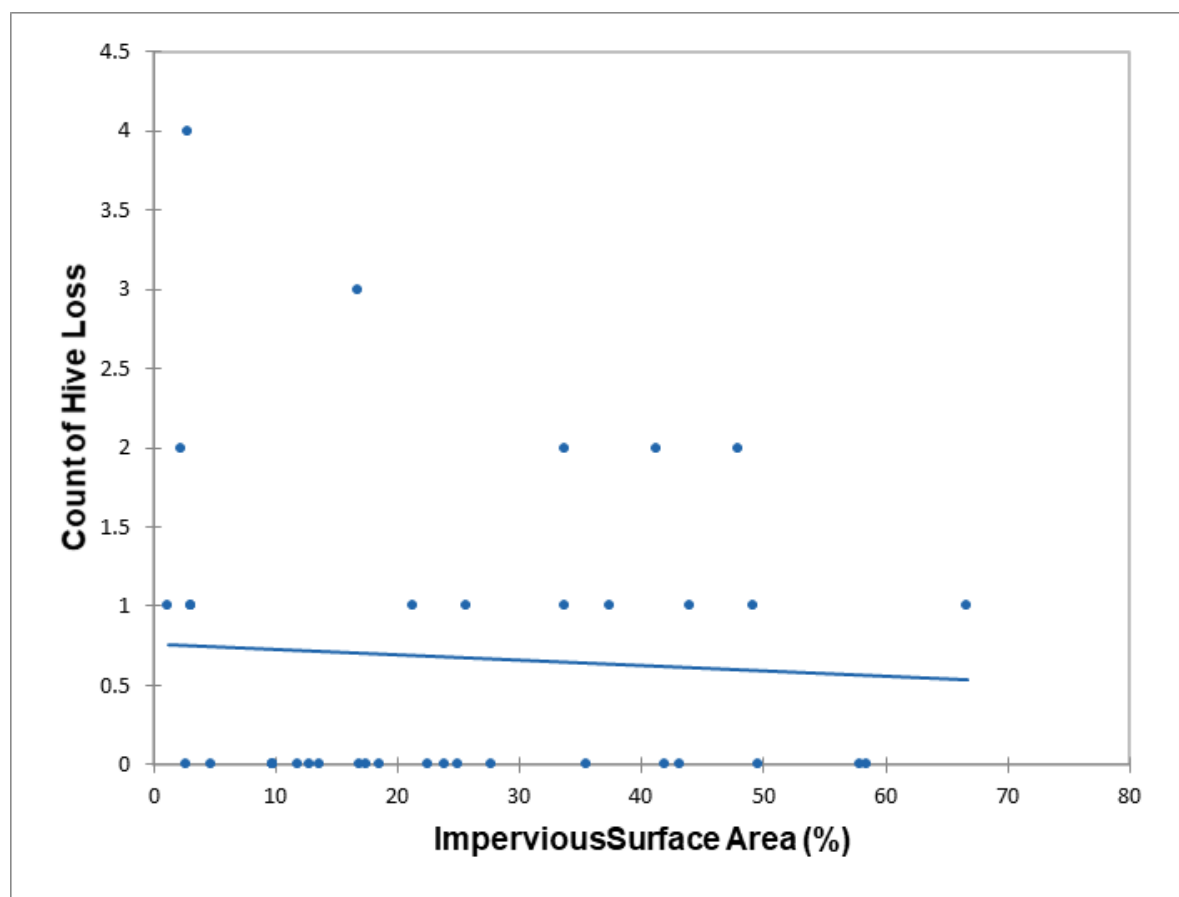

Fig. 9. Relationships between impervious surface percent and hive counts for hive gain (A) and hive loss (B) over the season. Spearman rho correlations for each of the response variables were not significant. 


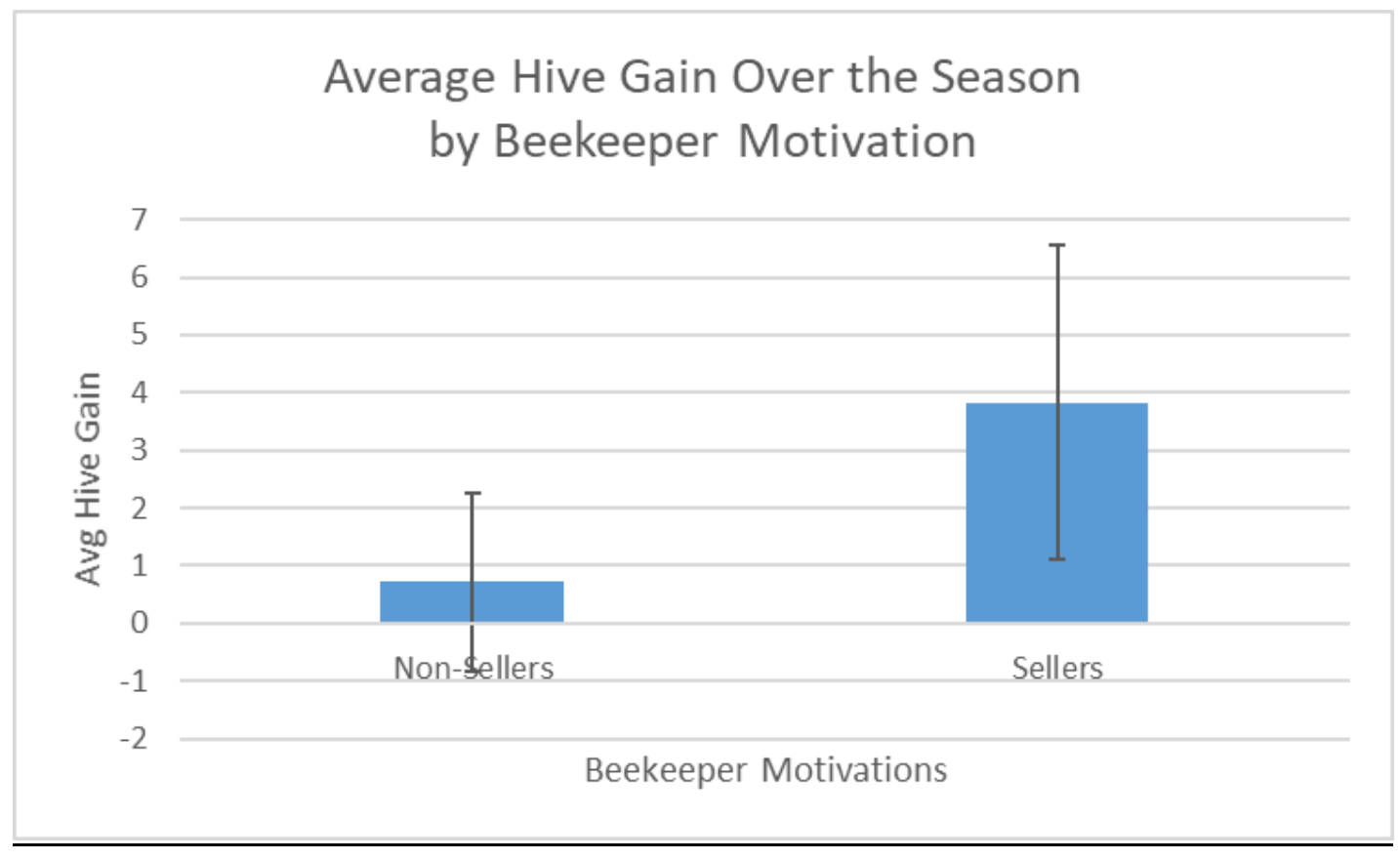

Fig. 10. Difference in the average number of hives gained over the season by beekeepers with different motivations for beekeeping. Motivation categories are determined by whether the beekeeper sells or does not sell any hive product (honey, beeswax, and/or bees). The Kruskal-Wallis test was used to determine that the difference between these two samples was significant ( $\mathrm{p}=<0.001)$. 


\section{APPENDIX 1 SURVEY QUESTIONS}

\section{KBA Beekeeper Survey 2017}

This is a short survey to participate in a research project at the University of Louisville. The goal of the project is to find location of honeybee hives belonging to members of Kentuckiana Bee Association and commercial apiarists in Jefferson County and their location mapped using GIS software. We will also be looking into general trends in the beekeepers traits like age, gender etc. Please only respond per family/hive owner(s).

Individuals who complete the survey and provide contact information will be put into a drawing for a $\$ 25.00$ gift card to Kelley Beekeeping. The public drawing will be random and occur at the January Kentuckiana Beekeeper Meeting. It will be announced through KBA and the winner will be contacted using the information provided.

Name

This is to help connect the demographic data with hive data and in case there are follow up surveys,

I have read the consent letter that was sent with this survey link

$\begin{array}{ll}0 & \text { Yes } \\ 0 & \text { No }\end{array}$

Did you own or manage any hives in 2016? *

$\begin{array}{ll}0 & \text { Yes } \\ 0 & \text { No }\end{array}$

Did you take the 2016 version of this survey?

o Yes, and my answers have stayed the same

o Yes, but some of my answers have changed

o No

o Maybe 


\section{KBA Beekeeper Information}

This section is to learn more about who are the beekeepers in the area. Our goal is to look at general trends within the beekeeper group.

\begin{tabular}{ll} 
Identified Gender \\
Multiple answers are allowed \\
$0 \quad$ Male \\
$0 \quad$ Female \\
o & Other \\
Age & \\
0 & $<18$ \\
0 & $18-24$ \\
o & $25-34$ \\
0 & $35-44$ \\
0 & $45-54$ \\
0 & $55-64$ \\
0 & $65+$ \\
\hline
\end{tabular}




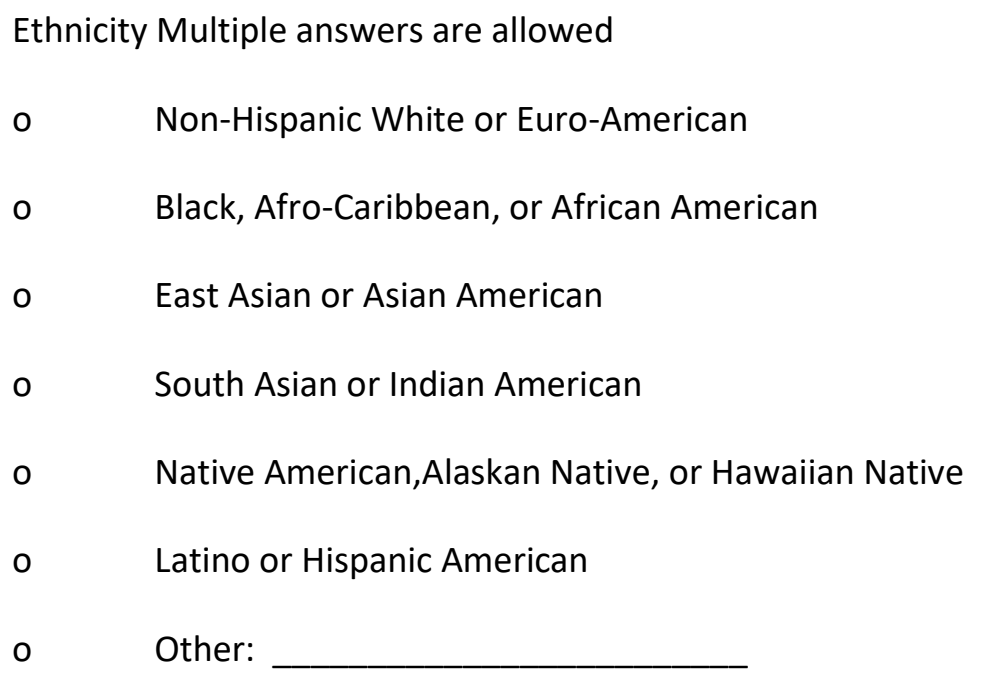

How long have you been an apiarist?

$\begin{array}{ll}0 & <1 \text { year } \\ 0 & 1-3 \text { years } \\ 0 & 3-5 \text { years } \\ 0 & 5-7 \text { years } \\ 0 & >7 \text { years }\end{array}$

Why do you keep bees? Multiple answers are allowed

- To sell related products

- Family tradition

- To help with local pollination

- Because it's enjoyable

o Other:

Does anyone else help you with your hives? If so, who?

Example: I am answering the survey, but really my husband and I are both beekeepers 


\section{KBA Hive Distribution and Health}

This section is for the distribution of hives, productivity of hives, and health The addresses will be used to find the general location of the hives owned. These locations will be turned into coordinates and not street addresses so as to not display members' whereabouts on the final map product. Our goal is to find out what determines hive survival and productivity. If you have provided your location in the 2016 survey and it has not changed, you may put "same as 2016"

What was the address of your hive(s) for most of the Spring and Summer seasons of 2017? *

Street address preferred, but if hive is at a location that does not have a specific address please provide name of area. Example: name of park, building, cemetery, farm. If you have provided your location in the 2016 survey and it has not changed, you may put "same as 2016"

Were your hives moved or rented out to a temporary location for their pollination services?

If yes please provide location(s) below

What will the address of your hive for most of the 2017/2018 Winter season?

What kind of hives do you use?

- Langstroth- 10 frames per medium or deep

- Langstroth- 8 frames per medium or deep

o $\quad$ Kenyan/Tanzanian-Horizontal Top Bar

o Warre- Vertical Top Bar

o Other

- Not Sure

How many colonies or hives did you have at the beginning of the Spring season?

How many colonies or hives did you have at the end of the season? 
If you gained or lost colonies or hives during Spring, Summer or Fall, what do you think was the cause?

Example: One of my colonies weakened and was taken over by a neighboring colony of mine, now the colony uses both sets of boxes OR I had a colony collapse, I suspect it was mite infestation OR My hives were doing well and I decided to add another in the middle of the season

Did you have any problems with pests or diseases this year? If so, what happened and how did you respond?

Example: Yes, I had a mite infestation in Hive 3 that I treated with Mite Away Quick Strips, they were ineffective OR Yes, my hives had a problem with hive beetles this year, but I left it alone and the bees fought them off

Were there any other treatments or supplements given to your hive? If so what and when?

Example: Yes, during the winter I set out syrup that I make with sugar and water, I also get pollen patties at the beginning of spring for growth

For the beginning of the season in Spring, how many frames were your colonies using?

If multiple hives, please specify if able. otherwise estimate Example: Hive 1 started with 2 medium boxes, $\mathrm{w} / 18$ of the 20 frames being used, Hive $2 \ldots$ Hive $3 \ldots$ etc. 
For the height of the season in Summer, how many frames were your colonies using?

If multiple hives, please specify if able. otherwise estimate Example: Hive 1 grew and had 2 deeps with 20 frames and a medium with 5 frames for honey, Hive 2... Hive $3 \ldots$ etc.

For the end of the season in preparation for Winter, how many frames were your colonies using?

If multiple hives, please specify if able. otherwise estimate Example: Hive 1 I took off the medium and condensed the hive back down to 2 deeps with 15 frames being used Hive 2... Hive 3... etc.

Did you harvest any frames for honey? If so, how much?

Weight or Volume is acceptable If your hives are in multiple locations please provide honey amounts per location. Examples: Yes, I harvested 8 frames from my medium super that were about $50 \mathrm{lbs}$ total before extraction OR Yes I harvested a couple of frames that had $36 \mathrm{oz}$ of honey after extraction

Did you harvest any frames for beeswax? If so, how much?

Any additional information, comments, or opinions? 


\section{Request for Contact Info}

Thank you for taking the time for this survey! I really appreciate your answers, and if you have any questions feel free to email me at: Haileighmw@gmail.com

May we contact you again if we have further questions?

o Yes

o No

What is the best way to reach you? (This is required for the giftcard drawing) 


\section{APPENDIX 2 SURVEY ANSWERS}

Appendix 2.1. Survey responses consisting of beekeeper demographic, experience, and motivation information used in this study.

Motivation reasons were coded as such: To sell related products (1), Family tradition (2), To help with local pollination (3), Because it's enjoyable (4), Other (5)

Ethnicity was coded as such: Non-Hispanic White or Euro-American (1), Black, AfroCaribbean, or African American (2)

\begin{tabular}{|c|c|c|c|c|c|c|}
\hline Timestamp & $\begin{array}{l}\text { Name } \\
\text { Code }\end{array}$ & $\begin{array}{l}\text { Identified } \\
\text { Gender }\end{array}$ & Ethnicity & Age & $\begin{array}{l}\text { Experience } \\
\text { Category }\end{array}$ & Motivation \\
\hline $10 / 14 / 2017$ & $\mathrm{JL}$ & Male & 1 & $55-64$ & $3-5$ years & 3 \\
\hline $10 / 15 / 2017$ & $\mathrm{JC}$ & Male & 1 & $35-44$ & $1-3$ years & 3,4 \\
\hline $10 / 24 / 2017$ & LA & Female & 1 & $35-44$ & $<1$ year & 5 \\
\hline $10 / 24 / 2017$ & KT & Female & 1 & $25-34$ & $<1$ year & $1,3,4$ \\
\hline $10 / 24 / 2017$ & RUS & Male & 1 & $65+$ & $3-5$ years & $1,3,4,5$ \\
\hline $10 / 25 / 2017$ & WW & Female & 1 & $45-54$ & $>7$ years & 3 \\
\hline $10 / 25 / 2017$ & $\mathrm{DL}$ & Male & 1 & $65+$ & $5-7$ years & 4 \\
\hline $10 / 26 / 2017$ & $\mathrm{KJ}$ & Male & 1 & $55-64$ & $>7$ years & $2,3,4$ \\
\hline $10 / 26 / 2017$ & $\mathrm{CT}$ & Male & 1 & $65+$ & 5-7 years & 3,4 \\
\hline $10 / 28 / 2017$ & $\mathrm{HBF}$ & Male & 1 & $45-54$ & $1-3$ years & $1,3,4$ \\
\hline $10 / 30 / 2017$ & $\mathrm{RF}$ & Female & 1 & $55-64$ & $3-5$ years & 3,4 \\
\hline $11 / 10 / 2017$ & $\mathrm{JM}$ & Male & 1 & $35-44$ & $>7$ years & $3,4,5$ \\
\hline $11 / 17 / 2017$ & $J D$ & Female & 1 & $45-54$ & $1-3$ years & 3,4 \\
\hline $11 / 19 / 2017$ & $\mathrm{BC}$ & Female & 1 & $65+$ & $5-7$ years & 3,4 \\
\hline $12 / 14 / 2017$ & LD & Male & 1 & $45-54$ & $1-3$ years & $1,3,4$ \\
\hline $1 / 15 / 2018$ & $\mathrm{ME}$ & Female & & $45-54$ & $1-3$ years & 4,5 \\
\hline $1 / 16 / 2018$ & $\mathrm{BR}$ & Female & 1 & $45-54$ & $1-3$ years & 4 \\
\hline $1 / 17 / 2018$ & $\mathrm{DR}$ & Male & 1 & $65+$ & $>7$ years & 1,4 \\
\hline $1 / 18 / 2018$ & $A C$ & Female & 1 & $35-44$ & $5-7$ years & $2,3,4$ \\
\hline $1 / 18 / 2018$ & PW & Male & 1 & $65+$ & $3-5$ years & 1,4 \\
\hline $1 / 19 / 2018$ & $\mathrm{RS}$ & Male & 2 & $45-54$ & $1-3$ years & 3,4 \\
\hline $1 / 19 / 2018$ & SB & Male & 1 & $55-64$ & 3-5 years & 3 \\
\hline $2 / 1 / 2018$ & $\mathrm{TL}$ & Male & 1 & $45-54$ & $5-7$ years & $1,4,5$ \\
\hline $2 / 9 / 2018$ & SC & Female & 1 & $25-34$ & $<1$ year & 4 \\
\hline $2 / 9 / 2018$ & CT & Female & 1 & $55-64$ & $1-3$ years & 4 \\
\hline From Paper & $\mathrm{LC}$ & Male & 1 & $45-54$ & $3-5$ years & $1,2,3,4$ \\
\hline $2 / 13 / 2018$ & $\mathrm{HBF}$ & Male & 1 & $45-54$ & $1-3$ years & 4 \\
\hline $2 / 14 / 2018$ & $\mathrm{RF}$ & Male & 1 & $45-54$ & $1-3$ years & 3,5 \\
\hline $2 / 22 / 2018$ & $\mathrm{JM}$ & Male & 1 & $25-34$ & $5-7$ years & $3,4,5$ \\
\hline From Paper & $\mathrm{JD}$ & Male & 1 & $45-54$ & $<1$ year & 3,5 \\
\hline
\end{tabular}


Appendix 2.2 Survey responses consisting of beekeeper answers regarding hive number and frames that were used as response variables in this study.

\begin{tabular}{|c|c|c|c|c|c|c|}
\hline \multirow[b]{2}{*}{$\begin{array}{l}\text { Name } \\
\text { Code }\end{array}$} & \multirow[b]{2}{*}{$\begin{array}{l}\text { Hive } \\
\text { Type }\end{array}$} & \multicolumn{2}{|c|}{ Hive Count } & \multicolumn{3}{|c|}{ Frame Count } \\
\hline & & Beginning & End & Beginning & Middle & End \\
\hline $\mathrm{JL}$ & 1 & 1 & 1 & don't know & don't know & don't know \\
\hline $\mathrm{JC}$ & 1 & 4 & 8 & $\begin{array}{l}4 \text { hives, each } \\
\text { running } \\
\text { Double } 10 \\
\text { frame deeps, }\end{array}$ & $\begin{array}{l}4 \text { established double } \\
\text { deeps, each with a } \\
\text { shallow super for } \\
\text { honey, and } 45 \text { frame } \\
\text { nucs building from a } \\
\text { grafted queen and } 4 \\
\text { drawn frames from } \\
\text { each of the } \\
\text { established colonies }\end{array}$ & $\begin{array}{l}8 \text { hives running } \\
\text { double deeps, } \\
\text { two of which still } \\
\text { have honey } \\
\text { supers that will } \\
\text { stay on for the } \\
\text { winter. }\end{array}$ \\
\hline LA & 1 & 4 & 2 & 10 frames each & 40 frames, 20 frames & $\begin{array}{l}40 \text { frames, } 20 \\
\text { frames }\end{array}$ \\
\hline KT & 1,3 & 2 & 2 & $\begin{array}{l}\text { Both hives } \\
\text { were started } \\
\text { this year, so at } \\
\text { the beginning } \\
\text { they were } \\
\text { using none }\end{array}$ & $\begin{array}{l}\text { Hive } 1 \text { (top bar) } 17 \text { of } \\
20 \text { frames used, Hive } 2 \\
\text { (langstroth) } 1 \text { deep } \\
\text { with } 10 \text { frames used } \\
\text { and one medium with } \\
5 \text { frames used. }\end{array}$ & $\begin{array}{l}\text { Hive } 1 \text { (top bar) } \\
20 \text { frames, Hive } 2 \\
\text { (Langstroth) } 15 \\
\text { frames overall }\end{array}$ \\
\hline RUS & 1 & Two & 8 & $\begin{array}{l}\text { Hive1 } 20 \\
\text { frames hive } 2 \\
\text { same }\end{array}$ & All hives all frames & All \\
\hline WW & 1 & 3 & 3 & $\begin{array}{l}2 \text { boxes of } 10 \\
\text { frames }\end{array}$ & Same & \\
\hline $\mathrm{DL}$ & 1 & 4 & 4 & 20 & 20 & \\
\hline KJ & 1 & 2 & 3 & $\begin{array}{l}\text { new hives } \\
\text { started with } 1 \\
\text { deep of } 10 \\
\text { frames; about } \\
7 \text { used }\end{array}$ & $\begin{array}{l}2 \text { deeps of } 10 \text { frames; } \\
\text { about } 16 \text { used }\end{array}$ & almost all \\
\hline CT & 1 & Two & 6 & $\begin{array}{l}\text { Hive bodies } \\
\text { were full so I } \\
\text { added supers } \\
\text { to allow } \\
\text { growth and } \\
\text { storage }\end{array}$ & $\begin{array}{l}\text { Two old hive were } \\
\text { using } 75 \% \text { and four } \\
\text { new hives were } \\
\text { starting over }\end{array}$ & $\begin{array}{l}\text { Two old hives had } \\
\text { grown full and } \\
\text { four swarm hive } \\
\text { lost to wax } \\
\text { moths. }\end{array}$ \\
\hline HBF & 2 & 14 & 17 & $\begin{array}{l}1 / 2 \text { of our } \\
\text { hives were } \\
\text { using less than } \\
8, \text { the other } \\
\text { half between } \\
10-14\end{array}$ & $\begin{array}{l}1 / 2 \text { of our hives did } \\
\text { well with } 2 \text { deeps and } \\
2 \text { supers of honey, the } \\
\text { other less than } 1 \text { full } \\
\text { super }\end{array}$ & $\begin{array}{l}1 / 2 \text { have } 1 \text { deep, } \\
\text { the other } 2 \text { deep }\end{array}$ \\
\hline
\end{tabular}


Appendix 2.2 cont.

\begin{tabular}{|c|c|c|c|c|c|c|}
\hline \multirow[b]{2}{*}{$\begin{array}{l}\text { Name } \\
\text { Code }\end{array}$} & \multirow[b]{2}{*}{$\begin{array}{l}\text { Hive } \\
\text { Type }\end{array}$} & \multicolumn{2}{|c|}{ Hive Count } & \multicolumn{3}{|c|}{ Frame Count } \\
\hline & & Beginning & End & Beginning & Middle & End \\
\hline $\mathrm{RF}$ & 1 & 5 & 4 & & $1-20,2-5,3-54-0,5-0$ & $\begin{array}{l}1-202-10,3- \\
10,4-10\end{array}$ \\
\hline$J M$ & 1 & 1 & 1 & 20 & $\begin{array}{l}\text { Hive } 1 \text { : Grew to } 2 \text { deeps } \\
\text { with } 20 \text { frames and } 3 \\
\text { supers with } 30 \text { shallow } \\
\text { frames. Hive } 2 \text { : Split and } \\
\text { grew to } 2 \text { deeps with } 20 \\
\text { frames and } 1 \text { supper } \\
\text { with } 10 \text { shallow frames. }\end{array}$ & 10 \\
\hline$J D$ & 1 & 1 & 0 & 10 & 25 & 0 \\
\hline$B C$ & 1 & 3 & 1 & $\begin{array}{l}\text { Hive } 1 \text {-36, Hive 2- } \\
\text { 10,Hive } 3-9\end{array}$ & $\begin{array}{l}\text { Hive } 1-60 \text {, Hive } 2 \text { - 12, } \\
\text { Hive } 3-10\end{array}$ & Hive 1 -36 \\
\hline LD & 1 & 3 & 11 & $\begin{array}{l}\text { Hive } 1 \text { ten deep, } \\
\text { hive } 2 \text { ten deep, } \\
\text { hive } 3 \text { ten deep } \\
\text { and } 10 \text { medium } \\
\text { above. }\end{array}$ & $\begin{array}{l}\text { Hives } 1,2, \& 3 \text { had, } 2 \\
\text { deeps with } 20 \text { frames } \\
\text { and one } 10 \text { frame } \\
\text { medium. Hives } 3 \text { and } 4 \\
\text { had two deeps with a } \\
\text { total of } 20 \text { frames each. } \\
\text { Hives } 5,6,7,8,9,10, \& 11 \\
\text { had one deep with } 10 \\
\text { frames. Two of those } \\
\text { hives expanded into } \\
\text { two deeps with a total } \\
\text { of } 20 \text { frames each. }\end{array}$ & $\begin{array}{l}\text { Same as } \\
\text { above. }\end{array}$ \\
\hline ME & 1 & 1 & 0 & $3 / 20$ & $12 / 20$ & Died out \\
\hline$B R$ & 1 & 2 & 4 & 10 & 10 & 10 \\
\hline DR & Other & 9 & 14 & $\begin{array}{l}\text { All were two } \\
\text { deeps, nine } \\
\text { frames per box. } \\
\text { Recollection is } \\
\text { that most were } \\
\text { quite strong in } \\
\text { upper box, but } \\
\text { lower largely } \\
\text { empty. I reversed } \\
\text { all of them. }\end{array}$ & $\begin{array}{l}\text { All eight holdover hives } \\
\text { were using almost all } 18 \\
\text { frames. Splits and } \\
\text { swarm colonies in single } \\
\text { nine-frame deeps. }\end{array}$ & $\begin{array}{l}\text { All hives are } \\
\text { two deeps, } \\
\text { nine frames } \\
\text { per } \\
\text { (Combined } \\
\text { single-deep } \\
\text { colonies) }\end{array}$ \\
\hline$A C$ & 1 & 3 & 3 & $\begin{array}{l}\text { Hive } 1=14 \\
\text { frames, Hive } 2= \\
10 \text { frames, Hive } 3 \\
=20 \text { frames }\end{array}$ & $\begin{array}{l}\text { Hive } 1=19 \text { frames, Hive } \\
2=18 \text { frames, Hive } 3= \\
20 \text { frames }\end{array}$ & $\begin{array}{l}\text { Hive } 1=11 \\
\text { frames, Hive } \\
2=12 \\
\text { frames, Hive } \\
3=16 \text { frames }\end{array}$ \\
\hline
\end{tabular}


Appendix 2.2 cont.

\begin{tabular}{|c|c|c|c|c|c|c|}
\hline \multirow[b]{2}{*}{$\begin{array}{l}\text { Name } \\
\text { Code }\end{array}$} & \multirow[b]{2}{*}{$\begin{array}{l}\text { Hive } \\
\text { Type }\end{array}$} & \multicolumn{2}{|c|}{ Hive Count } & \multicolumn{3}{|c|}{ Frame Count } \\
\hline & & Beginning & End & Beginning & Middle & End \\
\hline PW & 1 & Two & 4 & $\begin{array}{l}\text { Hive } 1 \text { started } 2 \\
\text { deep ) } \\
\text { hive2 started } 2 \\
\text { Deep) } 3 \text { started } 2 \\
\text { deep) } 4 \text { Started } 2 \\
\text { deep and } 2 \text { medium }\end{array}$ & $\begin{array}{l}\text { h } 1 \text { 20frames -h } 2 \\
20 \text { frames -h3 } 20 \\
\text { frames }- \text { h } 440 \\
\text { frames }\end{array}$ & $\begin{array}{l}20 \text { For hives } 1-2-3 \\
\text { but hive } 4 \text { had } 30\end{array}$ \\
\hline RS & 1 & 1 & 2 & $\begin{array}{l}2 \text { hives both started } \\
\text { with } 4 \text { frames ea. }\end{array}$ & $\begin{array}{l}1 \text { hive } 12 \\
\text { frames( } 2 \text { deeps), } \\
1 \text { hive } 10 \\
\text { frames( } 1 \text { deep } / 1 \\
\text { super) }\end{array}$ & $\begin{array}{l}2 \text { hives, } 12 \\
\text { frames each }\end{array}$ \\
\hline SB & 1 & 2 & 2 & $\begin{array}{l}\text { Hive } 1: 14 \text {, Hive } 2 \text { : } \\
\text { Package bees, new } \\
\text { hive }\end{array}$ & $\begin{array}{l}\text { Hive 1: } 1 \text { deep w/ } \\
10 \text { frames } 3 \\
\text { mediums with } 24 \\
\text { frames, Hive } 2: 2 \\
\text { Mediums, } 14\end{array}$ & $\begin{array}{l}\text { Hive 1: } 1 \text { deep, } 1 \\
\text { medium, Hive } 2: \\
\text { swarmed and the } \\
\text { remaining bees } \\
\text { died. }\end{array}$ \\
\hline TL & 1 & 4 & 3 & $\begin{array}{l}\text { each hive had one } \\
\text { single deep with } 10 \\
\text { frames }\end{array}$ & $\begin{array}{l}\text { each have had } 2 \\
\text { ten frame deeps } \\
\text { and } 2-3 \text { nine } \\
\text { frame shallows } \\
\text { (before harvest) }\end{array}$ & $\begin{array}{l}\text { We lost two hives } \\
\text { in the fall. The } \\
\text { remaining two } \\
\text { each had } 2 \text { ten } \\
\text { frame deeps going } \\
\text { into winter }\end{array}$ \\
\hline SC & 1 & 2 & 2 & $\begin{array}{l}\text { Each hive started } \\
\text { with } 9 \text { frames }\end{array}$ & $\begin{array}{l}\text { Hive } 1 \text { had } 2 \\
\text { deeps and } 18 \\
\text { frames, Hive } 2 \\
\text { had } 2 \text { deeps and } \\
1 \text { medium and } 27 \\
\text { frames. }\end{array}$ & 18 each \\
\hline CA & 1 & 1 & 2 & hive one-30 & $\begin{array}{l}\text { hive one- } 30 \text { plus } \\
\text { one super for } \\
\text { honey with } 10 \\
\text { frames. hive two } \\
\text { came in the fall }\end{array}$ & $\begin{array}{l}\text { hive one-30 } \\
\text { frames. Hive two- } \\
20 \text { frames }\end{array}$ \\
\hline
\end{tabular}


Appendix 2.2 Cont.

\begin{tabular}{|c|c|c|c|c|c|c|}
\hline \multirow[b]{2}{*}{$\begin{array}{l}\text { Name } \\
\text { Code }\end{array}$} & \multirow[b]{2}{*}{$\begin{array}{l}\text { Hive } \\
\text { Type }\end{array}$} & \multicolumn{2}{|c|}{ Hive Count } & \multicolumn{3}{|c|}{ Frame Count } \\
\hline & & Beginning & End & Beginning & Middle & End \\
\hline TS & 1 & 3 & 5 & $\begin{array}{l}\text { Roughly, on } \\
\text { average about 7- } \\
10 \text { frames } \\
\text { covering in } \\
\text { double deeps. } \\
\text { This early spring } \\
\text { but I don't recall } \\
\text { clearly }\end{array}$ & $\begin{array}{l}\text { Brood- At peak } \\
\text { covering } \\
\text { almost all } \\
\text { frames in } \\
\text { double deeps. } \\
\text { Had problems } \\
\text { with crowding } \\
\text { this year }\end{array}$ & $\begin{array}{l}\text { Covering } 10+ \\
\text { frames in most } \\
\text { hives in double } \\
\text { deeps }\end{array}$ \\
\hline BW & Other & 1 & 1 & 10 Deep frames & $\begin{array}{l}20 \text { deep } \\
\text { frames }\end{array}$ & 15 deep frames \\
\hline UKTWO & 1 & 1 & 6 & $\begin{array}{l}10 \text { out of } 20 \text { in } \\
\text { one hive }\end{array}$ & $\begin{array}{l}\text { I had } 3 \text { with } 2 \\
\text { deep each. } \\
\text { Then a single } \\
\text { deep, and a } \\
\text { nuc. }\end{array}$ & $\begin{array}{l}3 \text { hives (20 deep } \\
\text { frames) }\end{array}$ \\
\hline UKTHREE & Other & $\begin{array}{l}\text { One, but } \\
\text { have had } \\
\text { others and } \\
\text { assisted with } \\
\text { others. }\end{array}$ & 1 & $\begin{array}{l}5 \text { brood, } 5 \text { honey } \\
\text { in a medium } \\
\text { supers }\end{array}$ & $\begin{array}{l}5 \text { brood, } 25 \\
\text { honey over } 3 \\
\text { medium supers }\end{array}$ & $\begin{array}{l}\text { the bees had } \\
\text { plenty of honey } \\
\text { stores over } 3 \\
\text { medium supers, } \\
\text { but appararently } \\
\text { either left or died. }\end{array}$ \\
\hline DS & 1 & 1 & 1 & $\begin{array}{l}5 \text { deep from a } \\
\text { nuc }\end{array}$ & 16-18 frames & 18 \\
\hline
\end{tabular}


Appendix 2.3 Survey responses consisting of pest observations, reasons for hive gain and loss, and if there was treatment/supplementation by the beekeeper.

\begin{tabular}{|c|c|c|c|}
\hline $\begin{array}{l}\text { Name } \\
\text { Code }\end{array}$ & Pests & $\begin{array}{l}\text { Treatments and/or } \\
\text { Supplements }\end{array}$ & Gain/Loss Reasons \\
\hline $\mathrm{JL}$ & didn't check & No & didn't loose it \\
\hline $\mathrm{JC}$ & $\begin{array}{l}\text { None. But I'm } \\
\text { treatment free }\end{array}$ & None & $\begin{array}{l}\text { I grafted queens, had } 4 \text { successful nucs of } 6 \\
\text { by late May. Fully established by July. I also } \\
\text { caught one swarm, but it contracted } \\
\text { sacbrood and collapsed. }\end{array}$ \\
\hline LA & $\begin{array}{l}\text { Yes, varroa mite, } \\
\text { used treatment, } \\
\text { one colony died. } \\
\text { Other survived. }\end{array}$ & Yes for varroa mites. & $\begin{array}{l}\text { Varroa mites and swarming of caught } \\
\text { swarms. }\end{array}$ \\
\hline KT & No & No & $\begin{array}{l}\text { We started the Spring with two-- one died of } \\
\text { an extreme drop in temp in late April being } \\
\text { that they were new bees and had not even } \\
\text { fully made it out of the swarm box into the } \\
\text { hive yet. Caught an additional two swarms } \\
\text { in early summer to add to our one top bar, } \\
\text { totalling three. One swarm was very weak, } \\
\text { original queen died and the new queen was } \\
\text { very weak as well, so we combined the weak } \\
\text { swarm with the larger/stronger swarm to } \\
\text { end the summer with two hives. }\end{array}$ \\
\hline RUS & Yes, hive beetles & $\begin{array}{l}\text { Winter patties, Axalic } \\
\text { acid vapor }\end{array}$ & Gained 3 hives due to swarming \\
\hline WW & Hive beetles & No & \\
\hline DL & No & & No \\
\hline KJ & No & No. & \\
\hline $\mathrm{CT}$ & $\begin{array}{l}\text { Lost the four } \\
\text { swarm hives to } \\
\text { wax moths - } \\
\text { gutted all frames } \\
\text { to wax melter } \\
\text { and freezer to kill } \\
\text { all pests. }\end{array}$ & $\begin{array}{l}\text { Mite strips applied, } \\
\text { beetle traps installed } \\
\text { with pollen in center and } \\
\text { oil left and right. Close } \\
\text { watch attempting to stay } \\
\text { ahead of wax moth } \\
\text { without success. }\end{array}$ & Wax moths \\
\hline HBF & SMB but not bad & $\begin{array}{l}\text { Apaguard, sugar water, } \\
\text { pollen patties }\end{array}$ & $\begin{array}{l}\text { need more supplemental feed early in the } \\
\text { spring and late fall }\end{array}$ \\
\hline RF & $\begin{array}{l}\text { Had problems } \\
\text { with SHB in all } \\
\text { hives will treat. } \\
\text { Treated for mites } \\
\text { in all hives }\end{array}$ & $\begin{array}{l}\text { Feed sugar water all } \\
\text { summer and will put } \\
\text { fondant in the hives for } \\
\text { winter }\end{array}$ & $\begin{array}{l}\text { We lost one hive. I think it was do to missing } \\
\text { the loss of the queen. }\end{array}$ \\
\hline
\end{tabular}


Appendix 2.3 cont

\begin{tabular}{|c|c|c|c|}
\hline $\begin{array}{l}\text { Name } \\
\text { Code }\end{array}$ & Pests & $\begin{array}{l}\text { Treatments and/or } \\
\text { Supplements }\end{array}$ & Gain/Loss Reasons \\
\hline $\mathrm{JM}$ & $\begin{array}{l}\text { Horrible problems with } \\
\text { small hive beetles this year } \\
\text { and inexplicable } \\
\text { queenlessness (lost four } \\
\text { queens!). }\end{array}$ & $\begin{array}{l}\text { I treat with Probiotic } \\
\text { powder three times year. I } \\
\text { fed my hives in late winter } \\
\text { with a homemade feed } \\
\text { patty (protein \& sugar). }\end{array}$ & $\begin{array}{l}\text { My hives appeared to be doing } \\
\text { well all year long. I was able to } \\
\text { make a successful split to two } \\
\text { hives. However, I kept coming } \\
\text { back to find that my hives were } \\
\text { inexplicably queenless in the } \\
\text { midst of the Summer and Fall. I } \\
\text { have no explanation. Everything } \\
\text { seemed fine. }\end{array}$ \\
\hline$J D$ & $\begin{array}{l}\text { Wax worms destroyed my } \\
\text { colony }\end{array}$ & No & Wax worms \\
\hline $\mathrm{BC}$ & No & $\begin{array}{l}\text { during the late winter } \\
\text { Pollen Patty }\end{array}$ & $\begin{array}{l}\text { Hive } 2 \text { and } 3 \text { were weak and } \\
\text { probably robbed }\end{array}$ \\
\hline LD & $\begin{array}{l}\text { Lost hive } 3 \text { to Varroa mites. } \\
\text { Had to combine with } \\
\text { another hive. Treated all } \\
\text { hives with Apigaurd. Later } \\
\text { treated all with Oxalic acid } \\
\text { vapor. }\end{array}$ & $\begin{array}{l}\text { Fed sugar syrup to all hives } \\
\text { early spring and to all } \\
\text { young hives, some where } \\
\text { swarms caught and some } \\
\text { were cutouts. Added an } \\
\text { essential oil emulsion of } \\
\text { tea tree oil and } \\
\text { wintergreen oil a few times } \\
\text { while feeding }\end{array}$ & $\begin{array}{l}\text { One loss due to Varroa. Gained } \\
\text { the others from splits, swarms, } \\
\text { and cutouts. }\end{array}$ \\
\hline ME & $\begin{array}{l}\text { Wax moth-changed out } \\
\text { new box and froze frames }\end{array}$ & $\begin{array}{l}\text { Honey } b \text { healthy in spring } \\
\text { feeding }\end{array}$ & Wax moth \\
\hline BR & $\begin{array}{l}\text { Varroa, treated them with } \\
\text { apiguard and oxalic acid }\end{array}$ & $\begin{array}{l}\text { Honeybee healthy, some } \\
\text { syrup, some sugar cakes a } \\
\text { small amount of pollen } \\
\text { patties }\end{array}$ & Mites \\
\hline DR & $\begin{array}{l}\text { Hive beetles always an issue } \\
\text { but controlled fairly well } \\
\text { with vegetable oil traps. } \\
\text { Haven't tested for mites } \\
\text { because I no longer would } \\
\text { treat anyway. }\end{array}$ & $\begin{array}{l}\text { Fed a few hives with sugar } \\
\text { syrup to get through winter } \\
\text { if they were light. }\end{array}$ & $\begin{array}{l}\text { Added colonies through splits } \\
\text { and catching swarms. Lost } \\
\text { maybe four last winter to } \\
\text { starvation or inadequate } \\
\text { numbers. One absconded this } \\
\text { fall for unknown reasons. }\end{array}$ \\
\hline$A C$ & No & No & $\mathrm{n} / \mathrm{a}$ \\
\hline PW & beetles in all hives & pollen patties & Hive 3 taken by many hives \\
\hline RS & $\begin{array}{l}\text { hive } 1 \text { - Varroa bloom in Oct. } \\
\text { Installed apivar } \\
\text { strips/Nov(solved). Hive } 2 \\
\text { robbed by other feral hives } \\
\text { all summer. nearly flushed. } \\
\text { fed sugar/water into } \\
\text { Nov/Dec } 2017 \text { (stabilized) }\end{array}$ & $\begin{array}{l}\text { I feed } \mathrm{HBH}(\text { HoneyBee- } \\
\text { Healthy oils) all year, as } \\
\text { well as dry pollen } \\
\text { substitute in late fall/early } \\
\text { winter }\end{array}$ & $\begin{array}{l}\text { Lasy year was poor production } \\
\text { due to long dearth in area. I had } \\
\text { to feed all late summer/fall } \\
\text { approx } 20 \text { gallons(1-1/2-1 sugar } \\
\text { water) across both hives. }\end{array}$ \\
\hline SB & $\begin{array}{l}\text { No. I'm not sure why the } \\
\text { 2nd hive failed. }\end{array}$ & $\begin{array}{l}\text { Sugar water during winter } \\
\text { months }\end{array}$ & Swarm/weakened state \\
\hline
\end{tabular}




\begin{tabular}{|c|c|c|c|}
\hline $\begin{array}{l}\text { Name } \\
\text { Code }\end{array}$ & Pests & $\begin{array}{l}\text { Treatments and/or } \\
\text { Supplements }\end{array}$ & Gain/Loss Reasons \\
\hline TL & $\begin{array}{l}\text { hive beetle mostly; beetle } \\
\text { traps. Some wax moths when } \\
\text { in storage; worse than years } \\
\text { past }\end{array}$ & $\begin{array}{l}\text { spring \& fall syrup } \\
\text { feeding }\end{array}$ & $\begin{array}{l}\text { weakened colonies after } \\
\text { summer swarm ( } 2 \text { hives); } \\
\text { remaining } 2 \text { hives froze out } \\
\text { over the winter as temps got } \\
\text { warm, then subzero, then } \\
\text { warm again }\end{array}$ \\
\hline SC & $\begin{array}{l}\text { Each colony had hive beetles, } \\
\text { but I let them deal on their } \\
\text { own. Each had a manageable } \\
\text { mite presence. I used } \\
\text { Apiguard on both hives in the } \\
\text { fall. }\end{array}$ & $\begin{array}{l}\text { Spring and fall, I set out } \\
\text { sugar syrup, and have } \\
\text { been feeding } \\
\text { sugar/pollen patties } \\
\text { during winter }\end{array}$ & \\
\hline CA & $\begin{array}{l}\text { yes. hive beetles. got beetle } \\
\text { traps that go in-between } \\
\text { frames and dryer sheet type } \\
\text { plus under hive trap bottom } \\
\text { board. significant reduction } \\
\text { in beetles }\end{array}$ & $\begin{array}{l}\text { mite treatment in the } \\
\text { fall }\end{array}$ & $\begin{array}{l}\text { gained one colony. caught a } \\
\text { swarm late summer }\end{array}$ \\
\hline TS & $\begin{array}{l}\text { Mites (varroa destructor) } \\
\text { treated with Apivar in } \\
\text { summer and oxalic acid in the } \\
\text { fall }\end{array}$ & $\begin{array}{l}\text { Feed sucrose syrup } \\
\text { spring and fall }\end{array}$ & $\begin{array}{l}\text { Mites and poor swarm } \\
\text { management. } 3 \text { started }+2 \\
\text { package }+1 \text { split }+1 \text { swarm La } \\
\text { Minga }+1 \text { swarm from pks, } \\
\text { then lost } 3 \text { at La Minga }\end{array}$ \\
\hline BW & $\begin{array}{l}\text { i had small hive betles used } \\
\text { traps to controll and a drone } \\
\text { frame for mites }\end{array}$ & fall feeding & hive was fine \\
\hline UKTWO & $\begin{array}{l}\text { Had beetle } s \text { in one hive. Ants } \\
\text { moths }\end{array}$ & $\begin{array}{l}\text { Beetle traps, ant bait } \\
\text { stations, diatomaceous } \\
\text { earth around hives. } \\
\text { Mite treatment }\end{array}$ & $\begin{array}{l}\text { Lost one } 2 \text { hives to robbing. } \\
\text { Lost } 2 \text { hives in spring the day } \\
\text { they sprayed herbicide on the } \\
\text { wild flowers for the GMO } \\
\text { corn. }\end{array}$ \\
\hline UKTHREE & $\begin{array}{l}\text { there were a small population } \\
\text { of hive beetles, but they did } \\
\text { not survive after the freeze. }\end{array}$ & No. & $\begin{array}{l}\text { I think they either left on the } \\
\text { first warm day of this winter, } \\
\text { but I didn't see them leave, } \\
\text { there doesn't appear to be too } \\
\text { much die-off near the hive. }\end{array}$ \\
\hline DS & $\begin{array}{l}\text { Yes, small hive beetles- small } \\
\text { infestation so we left it alone. } \\
\text { Recently add swiffer pads to } \\
\text { entrap beetles }\end{array}$ & $\begin{array}{l}\text { provided a pollen patty } \\
\text { and sugar syrup in } \\
\text { November }\end{array}$ & $\mathrm{N} / \mathrm{A}$ \\
\hline
\end{tabular}


Appendix 2.4 Additional information gathered by contacted beekeepers individually that consists of who was contacted, why, how, and what was added to the study.

\begin{tabular}{|c|c|c|c|}
\hline $\begin{array}{l}\text { Name } \\
\text { Code }\end{array}$ & $\begin{array}{l}\text { Clarification } \\
\text { Needed }\end{array}$ & Method & Additions \\
\hline $\mathrm{JL}$ & Frame Info & Email & \\
\hline $\mathrm{JC}$ & Honey Info & Email & $\begin{array}{l}\text { Honey came from site } 1 \text {, some unharvested at site } \\
2\end{array}$ \\
\hline KT & Frame Info & Email & Top Bar frame equivalent to medium frames \\
\hline LA & Frame Info & Facebook & Was using deep boxes \\
\hline RUS & $\begin{array}{l}\text { Frame Info, Count } \\
\text { Info }\end{array}$ & Email & $\begin{array}{l}2 \text { packages, } 2 \text { hives swarmed and caught, } 2 \\
\text { inherited from friend } 8 \text { hives by height of summer, } \\
\text { Frames still unclear }\end{array}$ \\
\hline WW & Frame Info & Unable & Assumed deeps \\
\hline $\mathrm{DL}$ & Frame Info & Unable & Assumed deeps \\
\hline $\mathrm{KJ}$ & $\begin{array}{l}\text { Frame Info, Count } \\
\text { Info }\end{array}$ & Email & $\begin{array}{l}\text { Gained by swarm, almost all means } 20 \text { deep } \\
\text { frames }\end{array}$ \\
\hline $\mathrm{HBF}$ & $\begin{array}{l}\text { Frame Info, Count } \\
\text { Info }\end{array}$ & KBA Meeting & $\begin{array}{l}\text { Only half of hives in Oldham, Divided everything by } \\
2 \text {, took averages of hive frames }\end{array}$ \\
\hline $\mathrm{RF}$ & $\begin{array}{l}\text { Frame Info, Count } \\
\text { Info }\end{array}$ & Email, Phone & $\begin{array}{l}\text { Answered survey twice, using first, frames were } \\
\text { deeps }\end{array}$ \\
\hline JM & Frame Info & & Beginning and End Frames are deeps \\
\hline$J D$ & Frame Info & Unable & Assumed deeps \\
\hline $\mathrm{BC}$ & Frame Info & Email & $\begin{array}{l}\text { No answer, unable to assume deeps, did not use in } \\
\text { Frame analyses }\end{array}$ \\
\hline ME & Frame Info & Email & No answer, assumed deeps \\
\hline BR & $\begin{array}{l}\text { Frame Info, Count } \\
\text { Info, Honey Info }\end{array}$ & Facebook & $\begin{array}{l}\text { Frames are deeps, Gained before middle, honey } \\
\text { mixed }\end{array}$ \\
\hline DR & $\begin{array}{l}\text { Frame Info, Count } \\
\text { Info, Honey Info }\end{array}$ & $\begin{array}{l}\text { Email, KBA } \\
\text { Meeting }\end{array}$ & $\begin{array}{l}\text { Honey split in sites 50:25:25, gained/loss about the } \\
\text { same for each site, Gained swarms before middle }\end{array}$ \\
\hline AC & Frame Info & Facebook & Frames are mix of deep and medium, clarified \\
\hline PW & $\begin{array}{l}\text { Frame Info, Hive } \\
\text { Count }\end{array}$ & Phone & $\begin{array}{l}\text { Gained } 3 \text { swarms, lost } 1 \text { counted hive } 1 \text { and } 2 \text { for } \\
\text { beginning frame }\end{array}$ \\
\hline CA & Frame Info & Email & Confirmed deeps \\
\hline TS & Count Info & KBA Meeting & $\begin{array}{l}\text { Tracked gain/loss reasons, confirmed which hives } \\
\text { at which site }\end{array}$ \\
\hline UKTWO & Count Info & KBA Meeting & How gain/loss and when to clarify \\
\hline
\end{tabular}




\author{
\&8 55,\&8/ $80 \mathrm{~V}, 7 \$($ \\ + DQHJ KS\$ URQT \\ 2403 Sherry Road \\ Louisville, KY 40217 \\ Haileigh.white@louisville.edu
}

\title{
Education
}

2016-2018- MS-Interdiscliplinary Studies: Concentration in Sustainability, University of Louisville, Louisville, KY. Thesis Title: The Socio-Ecology of Managed Honeybees (Apis mellifera) in the Louisville Metro Area

2012-2016 -BS- Biology with Minor, Chemistry and Certification in Peace Studies and Conflict Transformation, University of Louisville, Louisville, KY.

\section{Employment Experience}

2016 (August-Present)- Graduate Research Assistant, School of Interdisciplinary and Graduate studies, University of Louisville, Louisville, KY.

2015/16 (September-May )- REACH LRC Tutor, University of Louisville, Louisville KY.

\section{Research Experience}

2017- (March-Present)- Graduate Research Assistant, School of Interdisciplinary and Graduate Studies, Biology Department, University of Louisville, Louisville, KY.

2016- (August-Present)- Masters of Science Thesis Research

2016- (November-December)- Group Research Project: Neighborhood Evaluation, Urban and Public Affairs with Partnership for a Green City, University of Louisville, Louisville, KY.

2015- (August-December)- Independent Research, Department of Biology, University of Louisville, Louisville KY.

2015- (August-December)- Research Project: Conservation of Endangered Species, Honors Department with $21^{\text {st }}$ Century Parks Inc, University of Louisville, Louisville, KY.

2015-(June-August)- Field Research Assistant (Summer Research), Department of Biology, University of Louisville, Louisville KY.

2014- (January- September)- Laboratory Research Assistant (Independent Study), Department of Biology, University of Louisville, Louisville KY 


\section{Presentation Experience}

2018-(February)- Presenter/Panelist, Dimensions of Political Ecology, University of

Kentucky, Lexington, KY "The Bills and The Bees: How Policy affects Local Beekeeper Organizations"

Awards

2016-2018- Graduate Research Assistant Fellowship, University of Louisville, Louisville, KY.

2012-2016-Trustees Scholarship, University of Louisville, Louisville, KY. 